The Cryosphere Discuss., 5, 41-73, 2011

www.the-cryosphere-discuss.net/5/41/2011/

doi:10.5194/tcd-5-41-2011

(c) Author(s) 2011. CC Attribution 3.0 License.

\title{
Velocity structure, front position changes and calving of the tidewater glacier Kronebreen, Svalbard
}

\section{Velocities and} calving Kronebreen

\section{Sund et al.}
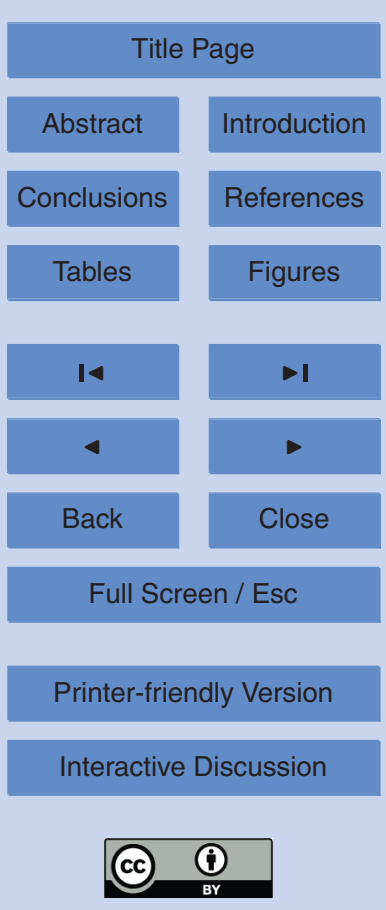


\section{Abstract}

Glacier calving and retreat constitute a substantial portion of the ablation of tidewater glaciers and is therefore of interest in climate models in order to get more accurate predictions of future development of glaciers and their contribution to sea level

5 rise. We use photogrammetry, global navigation satellite system, surface elevation and bathymetric data from Kronebreen to test a crevasse-depth calving model, investigate meteorological controls on near terminus velocity fluctuations and finally short-term and longer term (multi annual to decadal) controls of the front positions and calving. The relationship between velocity structure, crevasse formation, and calving events at 10 Kronebreen is found to be more complex than outlined in the crevasse-depth calving model. Surface meltwater is found to be closely connected to velocities, but no direct relationship between velocity variation and calving could be seen along the investigated transect. On a long term basis the front positions of Kronebreen are results of a combination of several factors, particularly the interplay with the confluent glacier

15 Kongsvegen, and change in discharge fluxes as a result of surge dynamics. Yet the bed topography is found to be an important control on the retreat of this glacier, similar to several other tidewater glaciers.

\section{Introduction}

Glacier calving constitutes a substantial portion of the ablation of high-latitude glaciers and ice sheets. More than $60 \%$ of the glaciers in Svalbard terminate in tidewater and thus exposed to calving and estimated to constitute $17-25 \%$ of the ablation of those glaciers (Błaszczyk et al., 2009). A major part of those are also found to be surgetype (Lefauconnier and Hagen, 1991; Sund et al., 2009) and are thus subject to large variations in calving rate.

25 Calving fluxes can undergo rapid changes in response to both external forcing (such as increases in atmospheric and oceanic temperature) or internal dynamics (such as

\section{Velocities and calving Kronebreen}

M. Sund et al.

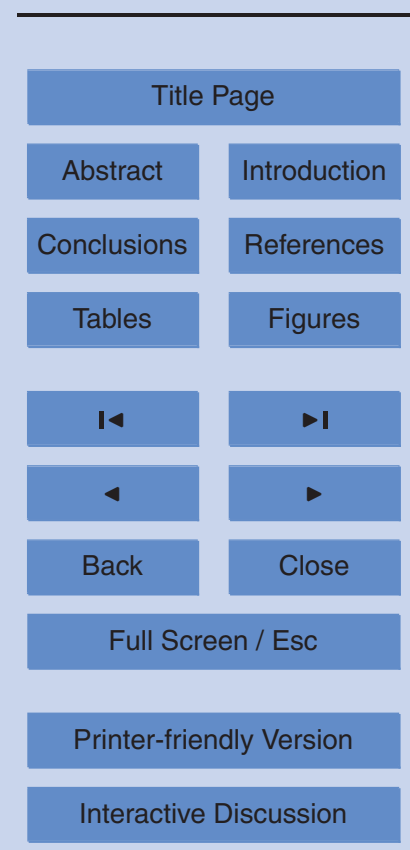


surges), and are therefore a major source of uncertainty in predictions of future sealevel rise (e.g., Meehl et al., 2007; Howat et al., 2007; Wingham et al., 2009). Improved predictions of future glacier mass changes and associated sea-level change will depend upon a deeper understanding of calving and associated dynamic processes, and 5 our ability to represent these processes in prognostic ice sheet models.

Field and remote sensing studies have shown that calving is a complex and diverse family of processes, with a broad range of environmental controls (Van der Veen, 2002; Benn et al., 2007a). This complicates any attempt to represent calving losses using formulations simple enough to incorporate in time-evolving ice-sheet models. Many 10 "calving laws" have been proposed, most of which are based upon empirical relationships established for small populations of glaciers or, in some cases, a single glacier (e.g., Brown et al., 1982; Sikonia, 1982; Warren et al., 1995a; Van der Veen, 1996; Alley et al., 2008). These laws tend to break down when applied to other glaciers, and none offers a robust, general means of parameterizing calving in all settings. In an attempt to overcome the limitations of empirical "calving laws", Benn et al. (2007b) proposed a physically based calving criterion, based on the idea that the first-order control on the position of a calving front is the velocity structure of the glacier tongue. Calving is assumed to occur when transverse crevasses (formed in response to extensional flow) penetrate some critical thickness though the ice. Crevasse depth is scaled to extensional strain rate (the along-flow velocity gradient), thus linking calving processes to glacier dynamics. Simulations using the crevasse-depth calving criterion exhibit a wide range of dynamic behaviour, including seasonal velocity and calving cycles (Nick et al., 2010). Despite these encouraging results, however, there remains a need for data to test whether the model provides a reasonable representation of calving processes in different situations.

Changes in water supply may also affect the future flow of the glacier, while calving is expected to increase and thus accentuating the contribution resulting from higher surface melt (Zwally et al., 2002). Variations in water supply as a result of changes in seasonal input are found to influence alpine glaciers (Iken and Bindscadler, 1986)

\section{TCD}

$5,41-73,2011$

\section{Velocities and calving Kronebreen}

M. Sund et al.

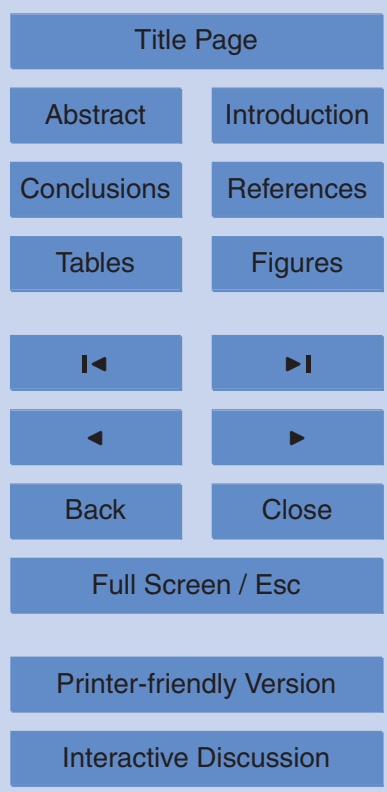


but also in Arctic tidewater glaciers (Vieli et al., 2004; Andersen et al., 2010). Also short-term velocity changes at the glacier terminus can impact a more long-term dynamic situation (Howat et al., 2010 and references therein) therefore knowledge of both velocity variations and structure could improve future prediction of calving responses.

5 Kronebreen is one of the continuously fastest flowing tidewater glaciers in Svalbard and is both a tidewater and surge-type glacier with a historic record of front positions.

In this paper we (1) test whether the current behaviour of Kronebreen can be adequately explained using the assumptions of the crevasse-depth calving model of Benn et al. (2007a, b). (2) Day-to-day velocity fluctuations near the calving front are - compared with meteorological parameters (air temperature, precipitation and river discharge) to asses the connection/influence of water input/meltwater on glacier velocity variations of this glacier and their (possible) role in the short term calving pattern. (3) Short-term and longer term (multi annual to decadal) controls of the front positions and calving of Kronebreen is investigated.

\section{Study area}

Kronebreen (Fig. 1) is a grounded tidewater glacier calving into Kongsfjorden in NorthWest Svalbard. Based on contour lines and velocity pattern (Liestøl, 1988; N. J. Schneevoigt, 2009, personal communication) it has an area of $\sim 530 \mathrm{~km}^{2}$, draining the icefields Dovrebreen, Holtedahlfonna and parts of Isachsenfonna. Kronebreen has a 175 year history of documented front positions and surged around 1869. It also has one of the continuously highest velocities measured in Svalbard (Liestøl, 1988), caused by a large accumulation area drained through a narrow channel. Velocities in the lower part have been studied for several decades, using different methods at various time-scales. The most accurate results are from short period averages (multi day) through a whole year achieved by photogrammetry on medium format images (e.g., Pillewizer, 1939; Voigt, 1967; Pillewizer and Voigt, 1968; Lefauconnier, 1987; Melvold, 1992; Rolstad, 1995; Kääb et al., 2005). Few measurements, however, have been made of short-term velocity variations near the calving ice-cliff.

\section{TCD}

$5,41-73,2011$

\section{Velocities and calving Kronebreen}

M. Sund et al.

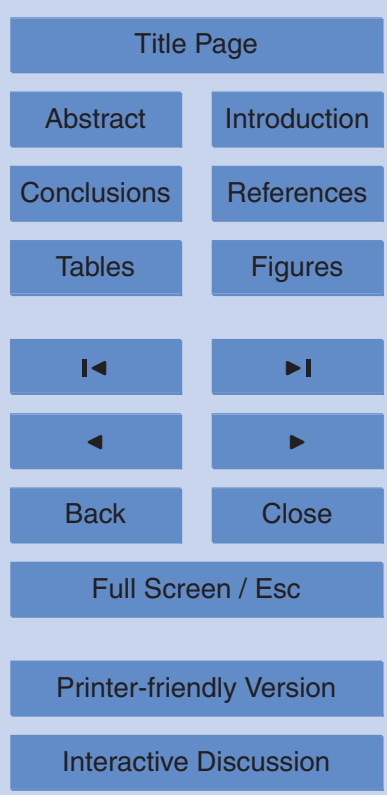


Approximately $5 \mathrm{~km}$ from its terminus, Kronebreen is confluent with Kongsvegen, and the boundary between the two glaciers is marked by a prominent medial moraine (Fig. 1). Kongsvegen surged and advanced 1.5 to $2 \mathrm{~km}$ around 1948 (Liestøl, 1988). Sea ice usually forms each winter in inner Kongsfjorden in front of Kronebreen and 5 breaks up during summer. Throughout the period covered by the time-lapse images used in this study it was absent.

\section{Methods}

\subsection{Ice velocity measurements}

To measure surface displacements in the terminal zone of the glacier, we used a pair of Single Lens Reflex (SLR) 10 Mpixel digital cameras $(c=28 \mathrm{~mm})$ programmed to acquire synchronous images at $6 \mathrm{~h}$ intervals. The cameras were installed $\sim 0.3 \mathrm{~km}$ apart at elevations of $375 \mathrm{~m}$ on the southern side of the mountain Colletthøgda (Fig. 1). The distance across glacier from the cameras was ca. $3 \mathrm{~km}$. Image pairs were used to generate stereo models, oriented using mountain tops and points at sea level. Features on the glacier surface were measured for extraction of velocities. Displacements were computed using both stereo solutions for two epochs, and daily displacements based on consecutive single image coordinates, from left and right camera, combined with distances to targets derived from the stereo results, following the method of Eiken and Sund (2011). Velocities were calculated for nine targets along a longitudinal transect (Fig. 1), for 3 June to 3 August 2008, with some data gaps when visibility was poor. Velocity measurements from stereo images rely on the identification of targets on two image pairs, separated by some time interval. While large-scale features such as crevasse-bounded blocks can be readily identified, several factors limited the precision with which small-scale targets such as sediment bands and pinnacles could be located. When the glacier front was snow-covered (June), precise target identification was particularly difficult. In addition; snow and ice melt introduced temporal variability

\section{Velocities and calving Kronebreen}

M. Sund et al.

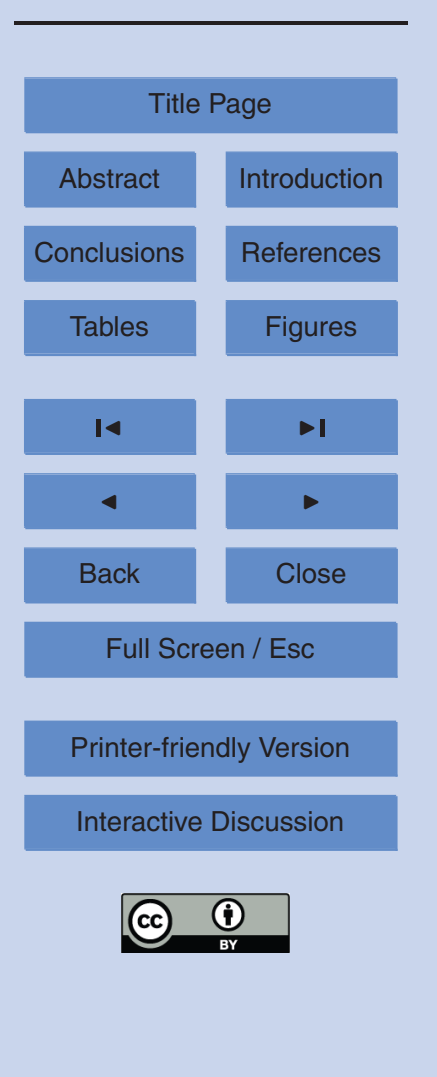


in glacier surface elevation and structure. The accuracy of the stereo solution in distance from camera, enforced by the short camera base and long distance, limits the usability of the results on a daily basis. The day-to-day measurements in each image were instead scaled with the distances found from the stereo solutions to form daily 5 displacements. Error estimates from corresponding left and right image results had average standard deviation of $0.35 \mathrm{~m}$ based on all measurements. Daily average standard deviation was $<0.5 \mathrm{~m}$ in 41 of the 49 observation sets. The glacier front positions were compiled from stereo models at start middle and end of season. The error increases with distance (from cameras) and the maximum error is estimated to $>10 \mathrm{~m}$ at $103 \mathrm{~km}$ distance for the front position.

Even though Kronebreen is one of the fastest glaciers in Svalbard, ice surface displacements over a $24 \mathrm{~h}$ period are small $(\sim 1.5-4.0 \mathrm{~m})$ relative to potential errors in target definition. Two approaches were made to overcome this problem. First, velocity measurements were made from image pairs from a single camera, combined with 15 distance-to-target determined from stereo imagery. This reduced the uncertainty associated with precise identification of target points viewed from two locations. Second, uncertainties were reduced by averaging data temporally. That is, the spatial velocity structure of the glacier terminus was determined by calculating velocities for multi-day periods. The methods used are thoroughly described by Eiken and Sund (2011).

Longer term average velocities were also determined using relative Global Navigation Satellite Systems (GNSS) survey of a stake emplaced on the glacier surface $2 \mathrm{~km}$ from the ice front on 30 May 2008 (Fig. 1). The stake was measured four time using Leica 1200 series receivers, relative to a base station at the nearby mountain Colletthøgda or the International GNSS Service (IGS) reference station at Ny-Ålesund.

\subsection{Calving magnitude and frequency}

Glacier front positions were determined from the stereo images, and daily assessments of calving magnitude were made using the subjective evaluation method of O'Neel et al. (2001). The terminus was divided into 4 sections and calving losses in each

\section{TCD}

5, 41-73, 2011

\section{Velocities and calving Kronebreen}

M. Sund et al.

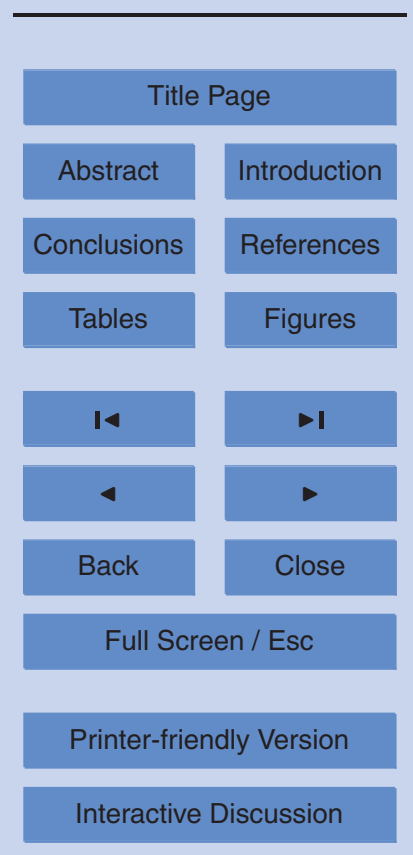

Interactive Discussion 
section were rated from 1 to 5 (small to large). A calving score was calculated for each time interval by summing the values for each sector, producing a 20-point scale. Caution is required when interpreting the results, because calving losses are more easily determined for the sectors closest to the cameras. However, they do represent 5 calving activity on an approximate ordinal scale, which can then be correlated with glacier velocity fluctuations and other possible controls.

\subsection{Meteorological and water discharge data}

To investigate possible controls on velocity and calving variations, air temperature, precipitation and river discharge data were used as proxies for water input to the glacier.

10 Daily average air temperature and precipitation data are available for $\mathrm{Ny}$-Ålesund, $14 \mathrm{~km}$ west of the Kronebreen front collected by the Norwegian Meteorological Institute (met.no), and water discharge data from Bayelva, $2 \mathrm{~km}$ west of Ny-Ålesund, were provided by the Norwegian Water Resources and Energy Directorate (NVE). The water discharge data are for a catchment with 55\% glacier cover (Pettersson, 1994). Al15 though they do not directly represent the discharge of Kronebreen, the temperature and precipitation data give an indication of probable variations in surface water production and subglacial discharge. The data were quality controlled by the respective institutions. The height of the stake established on Kronebreen in early June 2008 was also measured in order to estimate the melt during summer.

\subsection{Digital elevation models}

Digital Terrain Models (DTM) from 1964 and 2007 were used to evaluate long-term changes in the surface topography of the glacier. The contourlines of the map Indre Kongsfjorden 1:25000, Pillewizer and Voigt (1968), compiled from 1964 photographs, were digitized and gridded to a DTM with $40 \mathrm{~m}$ cellsize, and a 2007 DTM from Système Probatoire pour l'Observation de la Terre (SPOT) SPOT-5 HRS, $40 \mathrm{~m}$ grid size (Korona et al., 2009), with $10 \mathrm{~m}$ estimated accuracy (Bouillon et al., 2006) were used

\section{TCD}

$5,41-73,2011$

\section{Velocities and calving Kronebreen}

M. Sund et al.

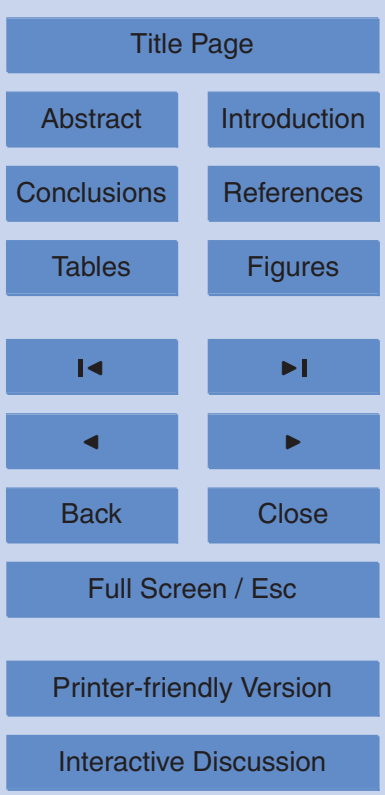


to evaluate changes and similarities in the surface topography. The SPOT-5 geocorrected image has also been used as background for other measured front positions in addition to comparisons with front positions on A7 Kongsfjorden maps from Norwegian Polar Institute (NPI).

\section{3.5 Fjord bathymetry and glacier bed topography}

Bathymetric data from two sources were used in this study. First, water depths in the fjord west of Kronebreen were measured using a Garmin 520s echo sounder in $200 \mathrm{kHz}$ narrow beam mode mounted on a small craft. Depths were measured every second and cruising speed was maximum $10 \mathrm{~km} / \mathrm{h}^{-1}$. The echo sounder was 10 not calibrated, but soundings in areas covered by the Norwegian Mapping Authority, Norwegian Hydrographic Service were carried out as a comparison and corresponded well. The absolute errors in the data are thus unknown but the relative errors in the data are minimal. Norwegian Mapping Authority, Norwegian Hydrographic Service also acquired data in 2010 from a vessel using a multi beam echo sounder EM3002 with 15 depth range to $150 \mathrm{~m}$.

\section{Results}

\subsection{Surface topography and elevation changes}

The two DTMs divided by $\sim 40$ years were compared with respect to surface topography structure and changes. Both reflect the post-surge adjustment of Kongsvegen and DTM (Fig. 2a), the line of contact between Kronebreen and Kongsvegen lies further north than at present, a legacy of the 1948 surge of the latter glacier. In the 2007 DTM (Fig. 2b), the line of contact has adjusted towards the south, and lies close to the pre-surge advance position of 1936 (Fig. 5a). In 1936 the width of Infantfonna

\section{TCD}

$5,41-73,2011$

\section{Velocities and calving Kronebreen}

M. Sund et al.

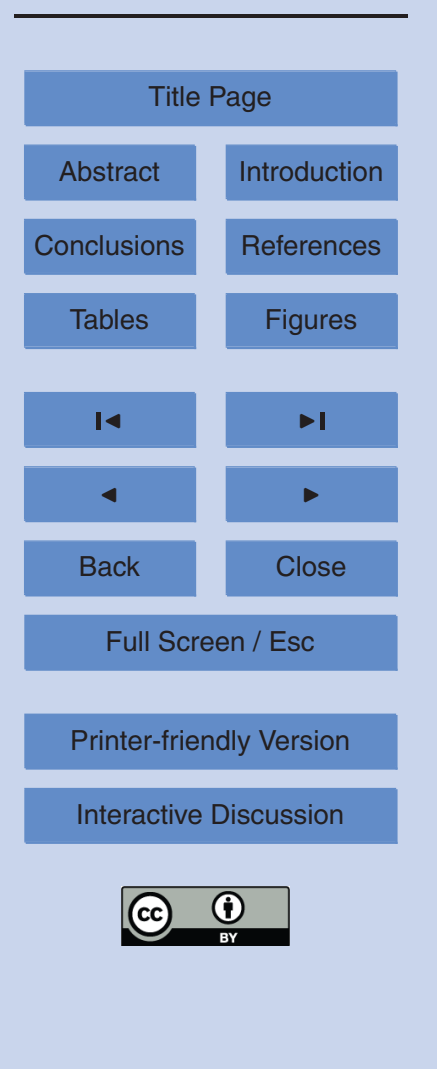


and Kongsvegen was almost equal and together constituted $\sim 25 \%$ of the total width of the ice cliff dominated by Kronebreen (A7 Kongsfjorden, 1990 ed. NPI). By 1964 Kongvegen was being pushed towards south, the Infantfonna stream was no longer extending all the way to the sea and Kronebreen covered $65 \%$ of the width (Voigt, 5 1967). By 2007 the partition between the three streams was almost back to the 1936 situation as Kronebreen occupied $\sim 70 \%$ of the width.

On both the 1964 and 2007 DTMs, prominent longitudinal ridges are present on the glacier surface, along the northern margin and the centre line of Kronebreen. The ridges are separated by a slight surface depression. These stable surface features 10 closely correspond to high and low points on the glacier bed. The centreline surface ridge lies above a prominent longitudinal ridge near the centre of the trough, whereas the northern ridge lies above a subglacial bench. The intervening surface hollow overlies an overdeepening on the bed, which has a maximum depth of ca. $80 \mathrm{~m}$. In addition, the 2007 DTM exhibits a surface depression close to the confluence with Kongsvegen, 15 which also corresponds to a depression on the glacier bed. The up-glacier end of the velocity transect (Fig. 1) overlies an overdeepening in the bed ( $\sim 80 \mathrm{~m}$ below sea-level), whereas the downglacier end overlies part of a major transverse ridge. The calving front is grounded in $\sim 60 \mathrm{~m}$ of water (J. Kohler, 2010, personal communication). The ridge transversal ridge is reflected in the surface topography through several decades

(Fig. 2a, b). The calving front of Kongsvegen is now very restricted in extent, and most of this glacier terminates on-land.

Long-term patterns of elevation change on the lower tongue of Kronebreen were determined by comparing DTMs for 1964 and 2007 (Fig. 2c). All parts of the lower tongue of the glacier have lowered between 1964 and 2007, with the greatest amount of lowering occurring in the south, in the area formerly occupied by Kongsvegen. The surface melt at the stake ( $\sim 110 \mathrm{~m}$ a.s.l.) showed melt of $\sim 3 \mathrm{~m}$ water equivalent (w eq.) during the summer 2008 season (30 May-28 September), of which 15\% melted in September.

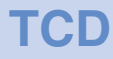

$5,41-73,2011$

\section{Velocities and calving Kronebreen}

M. Sund et al.

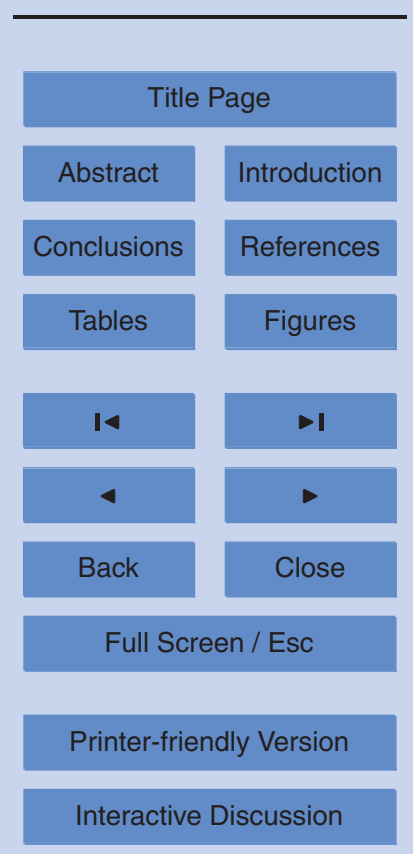

Interactive Discussion 


\subsection{Crevasse patterns and velocity structure}

In 1936 the glacier front was $\sim 4 \mathrm{~km}$ northwest of the current position (Fig. 5a). The crevasse pattern on 1936 aerial photos (NPI) shows decrease of crevasse width where the ice flows past Colletthøgda and into the area of the current terminus, indicating 5 an area with compressive flow at that time. The pattern of decreased crevasse width follows the transversal ridge (Sect. 4.1) an easterly inclined line from the west end of Colletthøgda towards the south side of Kongsvegen. This coincides with the surface contour line pattern (Fig. 2a, b, blue oval).

The current crevasse field near the terminus of Kronebreen reflects a combination of local and upglacier flow conditions. The crevasse field originates in an icefall about $12 \mathrm{~km}$ from the terminus, at an elevation of $\sim 500 \mathrm{~m}$ a.s.l., where it consists mainly of transverse crevasses (Fig. 1). This simple crevasse pattern is overprinted by a more complex one between 9 and $6 \mathrm{~km}$ from the front. Around $6 \mathrm{~km}$ from the front, additional transverse crevasses are formed, which are then rotated by shearing, particularly close to the northern margin, In the lowermost $5 \mathrm{~km}$ of the glacier, crevasses advected from upglacier are locally overprinted by chevron and longitudinal crevasses, creating a complex reticulate maze of fractures, ice blocks and seracs. In the lowermost $2 \mathrm{~km}$ of the glacier, a zone of longitudinal crevasses occurs close to the centreline. This zone coincides with a major longitudinal ridge at the glacier bed (Sect. 4.1), and likely reflects locally compressive flow. Transverse crevasses associated with extending flow are widespread to the north and south of the glacier centreline, and are associated with overdeepenings on the bed.

Photogrammetry was used to determine surface velocities along a longitudinal transect located to the north of the glacier centreline. A 60 day period with 50 near daily measurements is selected for this study, averaging left and right camera results for daily displacement. Standard deviation of the daily average of each target is estimated from the two observations. Large variations between days and targets are found, with average standard deviation of $0.35 \mathrm{~m}$ and daily displacements of $1.4-3.8 \mathrm{~m}$. To reduce the

\section{TCD}

$5,41-73,2011$

\section{Velocities and calving Kronebreen}

M. Sund et al.

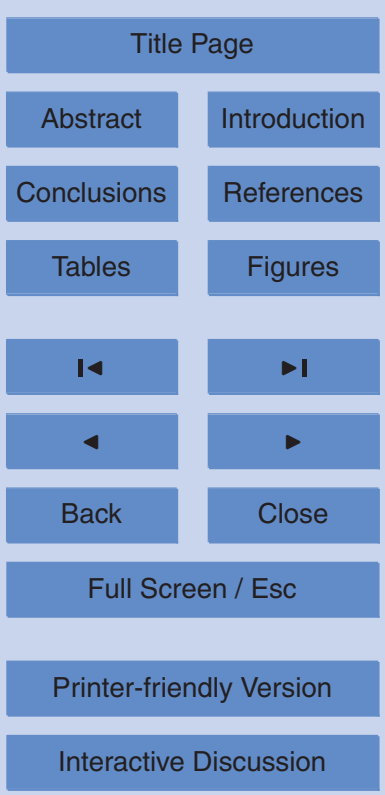


effects of random errors the results are cumulative over several days (Fig. 3a). A trend of slight velocity increase towards the terminus appears. The most pronounced gradient occurs between target 4 and 6 , where the cumulative displacement rises from ca. 138 to $154 \mathrm{~m}$ over the two month period, which amounts to $10 \%$ increase along 5 a distance of $\sim 200 \mathrm{~m}$.

The displacements along the transect were also averaged over two periods (Fig. 3b) of multiple weeks. An increase in velocity appears between 300 and $500 \mathrm{~m}$ from the front (as defined by 3 August). The increase in velocities is slightly higher early during period 1 when velocities are lower (14\%) than later in period 2, when the average 10 velocity is higher (11\%). This could be related to the spring speed-up and snow melt influenced the lowermost parts before affecting higher areas.

For both periods, there is a zone of extending flow upglacier $\sim 300 \mathrm{~m}$ from the terminus, and a zone of generally constant velocities or slightly compressive flow nearer the terminus. Following Hook (2005) method strain rates were calculated and extensional 15 strain rate is greatest between targets 5 and 6 in the first period, and between targets 4 and 5 in the second period, with strain rates of 0.70 and $0.68 \mathrm{a}^{-1}$, respectively.

Evidence for extending flow above the overdeepening suggests that transverse crevasses may be reactivated and deepened in this region. An estimate of crevasse depth can be obtained using the formula derived by Nye (1957):

$20 \quad d=\frac{2}{\rho_{i} g}\left(\frac{\dot{\varepsilon}_{x y}}{A}\right)^{1 / n}$

where $d$ is crevasse depth, $\rho_{i}$ is ice density, $g$ is gravitational acceleration, $\dot{\varepsilon}_{x y}$ is longitudinal strain rate, and $A$ and $n$ are the parameters in Glen's Flow Law. This formula is based on the assumption that crevasses will extend to the depth where tensile stress exactly equals overburden pressure, and ignores the effects of stress concentrations or standing water in the crevasses. In studies conducted by Mottram and Benn (2009), crevasse depths predicted by this formula were found to compare well with observations. For the strain rates calculated for the two periods, Eq. (1) yields

\section{TCD}

$5,41-73,2011$

\section{Velocities and calving Kronebreen}

M. Sund et al.

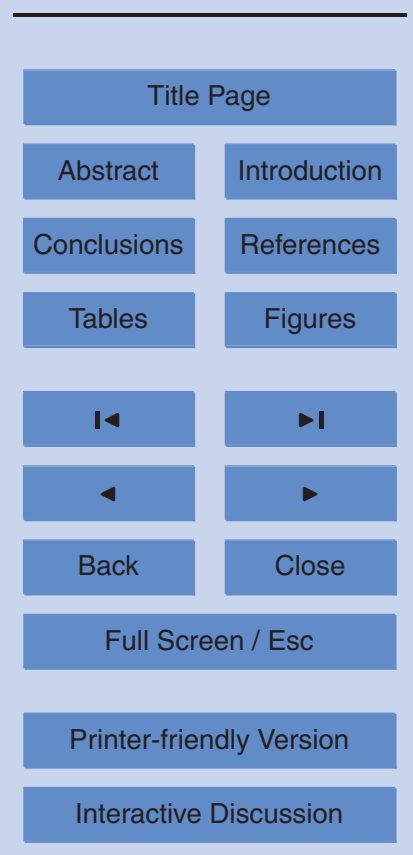


crevasse depths of $\sim 28 \mathrm{~m}$. These values fall within the range of measured ice cliff heights at the calving front of Kronebreen $(10-60 \mathrm{~m})$. The ice cliff height is $\sim 43 \mathrm{~m}$ at target 9 .

\subsection{Velocity fluctuations and calving}

5 Day-to-day velocities were calculated from photogrammetric measurements. During snowmelt (June) large changes occurs in surface structure on the lower glacier and introduces error in the measurements, which is especially visible when comparing results from the left and right camera. The errors and implications are discussed further by Eiken and Sund (2011). Later in summer (July) such errors are reduced as melting of ice causes less visual changes than snow. The time series of velocities is derived from the individual image measurements combined with stereo solution distances (Fig. 4). The estimated standard deviation is on average $15 \%$ of the daily displacements.

From the beginning of the record on 3 June there is a general increase in velocity to a peak of $\sim 2.5 \mathrm{~m} \mathrm{~d}^{-1}$ on 15 June. Following a period of lower velocities, there is a major 15 speed-up on 26-27 June, with peak velocities of $\sim 3.5 \mathrm{~m} \mathrm{~d}^{-1}$. Note, however that these two days velocities are based on $36 \mathrm{~h}$ average which could give slightly higher velocities than the $24 \mathrm{~h}$ mean. The record is intermittent for the following weeks, but velocities are typically around $2.5 \mathrm{~m} \mathrm{~d}^{-1}$ until they rise to a second peak on 25-26 July. The two major speed-ups both coincide with periods of high temperatures and discharge from 20 Bayelva.

GNSS measurements of the stake later in the season show that there was in increase in average velocity during the month of September $\left(2.1 \mathrm{~m} \mathrm{a}^{-1}\right)$, relative to June-August $\left(1.8 \mathrm{~m} \mathrm{a}^{-1}\right)$. Anomalously high precipitation and temperatures occurred in mid September (Fig. 4) and the weather conditions resulted in $15 \%$ of the result of the seasonal surface melt (Sect. 4.1). A time-lapse camera monitoring Comfortlessbreen, $15 \mathrm{~km}$ south of Kronebreen, showed that the glacier was covered by snow down to sea level at the beginning of September before the rain event. The snowline had risen to approximately $500 \mathrm{~m}$ a.s.l. by 20 September, indicating large water production by melting

\section{Velocities and calving Kronebreen}

M. Sund et al.

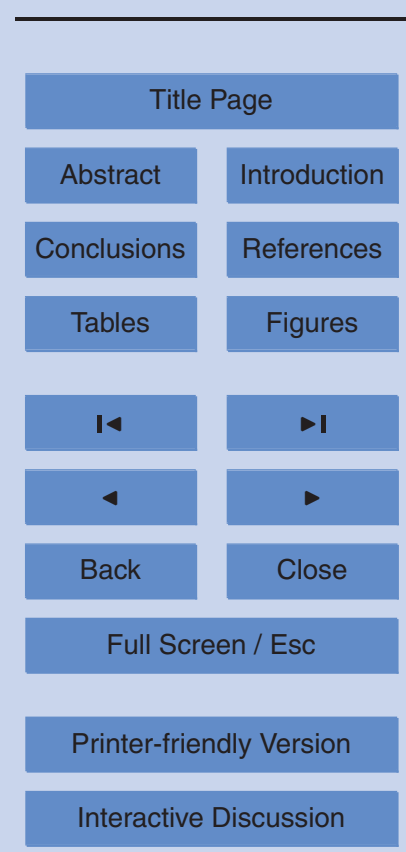


as well as direct inputs from rain. Similar conditions were present at Kronebreen according to the additional $15 \%$ surface melt measured at the stake during this period (Sect. 4.1). The velocity of the stake (Table 1) are referring to a position $>1 \mathrm{~km}$ upglacier of the uppermost target for photogrammetry measurement, and might have an

5 average velocity lower than in the area of the photogrammetric targets.

Calving activity shows no clear relationship with either the velocity record or meteorological variables. The increase in calving activity in early June may mark the transition from the low calving activity typical of the winter months to generally higher activity in the summer, but thereafter major calving events appear to occur more or less randomly. 10 During the summer of 2008 , the general pattern was that the ice front retreated during a calving event (or series of events) and then advanced towards more or less the same position before the cycle began afresh. Overall, the data suggest a largely stochastic calving process causing the glacier front to fluctuate around a quasi-stable position. The time-lapse photos show that calving events typically occur by the collapse of ice 15 pinnacles. Some of the larger calved blocks were bounded by crevasses advected from upglacer, but small- to medium-scale calving events commonly involved the release of smaller fragments along new fractures. Some undercutting of the front could be seen from sea, indicating that this process also may contribute to the smaller events.

\subsection{Long-term front position changes}

20 Front positions from various years before and after the Kongsvegen surge (Liestøl, 1988) are compared with the bathymetry in the area (Fig. 5). A large retreat of up to $1.4 \mathrm{~km}$ occurs between 1923 and 1924 and corresponds with a deeper area. After the Kongsvegen surge of $\sim 1948$, the Kronebreen-Kongsvegen glacier system has undergone progressive thinning (Sect. 4.1) and ice-front retreat. During 22 years after the 25 surge the retreat rate is $45-112 \mathrm{~m} \mathrm{a}^{-1}$, as the glacier retreats into gradually deeper water. The most rapid phase of retreat occurred between 1970 and 1976, when the

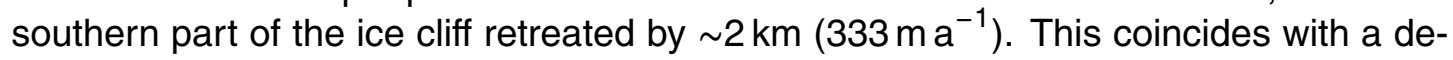
pression in the sea floor in this area. The retreat rate was much lower in the north,

\section{TCD}

$5,41-73,2011$

\section{Velocities and calving Kronebreen}

M. Sund et al.

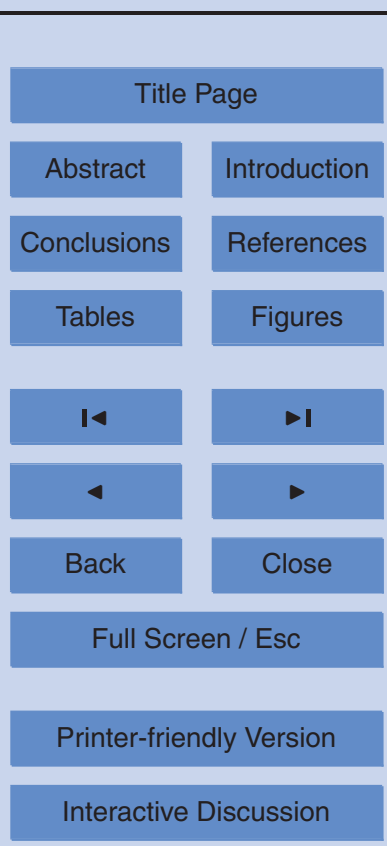


where the glacier margin remained close to the promontory to the west of Colletthøgda. The following 11 years to 1987 , the retreat rate is maximum $120 \mathrm{~m} \mathrm{a}^{-1}$. Glacier front positions for selected years between 1987 and 2008 are shown in Fig. 6. Most parts of the glacier front experienced net retreat over this period. The greatest amount of 5 net retreat occurred on the northern side of Kronebreen, which retreated up to $330 \mathrm{~m}$ $\left(\sim 20 \mathrm{~m} \mathrm{a}^{-1}\right)$ between 1990 and 2007. Further south towards Kongsvegen, a net retreat of ca. $200 \mathrm{~m}$ is observed in the same period. Near the centre of the glacier, where there is currently a slight headland in the calving front, there was a deep embayment in the 1990s, so little net change has occurred in the calving front position in this area. 10 This location coincides with a major longitudinal ridge on the glacier bed (Sect. 4.1). The 1998 ice-front position lies up to $200 \mathrm{~m}$ west of the 1990 position, suggesting a readvance of the glacier during the 1990s. It should be noted that the positions for 1987, 1990 and 1998 are single-day "snapshots", yet all are acquired in summer. Still major calving events might have occurred shortly before or after images were acquired.

Front positions during the summers of 2007 and 2008 (Fig. 6) derived from stereo measurements indicate an area where the variations are very small. This area coincides with the junction between a major transverse ridge and a major longitudinal ridge on the glacier bed, where water depths are relatively low.

\section{Discussion}

\subsection{Velocity structure and crevassing}

On Kronebreen, the spatial pattern of summer velocities determined by photogrammetry displays a consistent pattern, with a zone of flow acceleration between 270 and $540 \mathrm{~m}$ from the terminus, and a region of constant or slightly decelerating flow nearer the calving front. This kind of pattern has been observed on several other glaciers, where it has been attributed to decoupling at the glacier bed associated with a transition from grounded to buoyant or near-buoyant conditions (O'Neel et al., 2001;

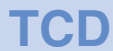

$5,41-73,2011$

\section{Velocities and calving Kronebreen}

M. Sund et al.

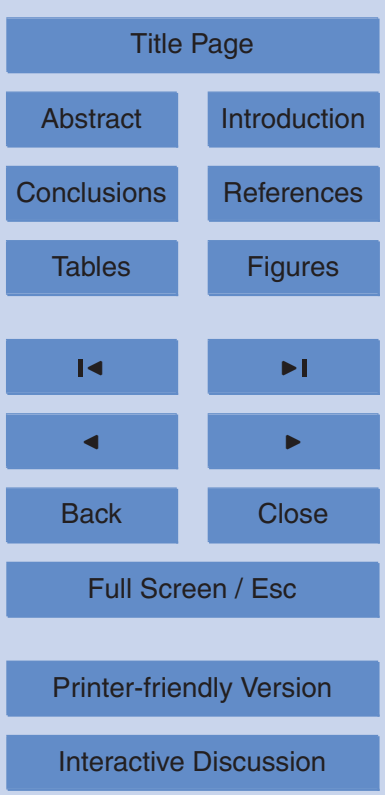


Krimmel, 2001; Björnsson et al., 2001). At Kronebreen, however, the zone of zero or compressive strain coincides with a major transverse ridge on the glacier bed, and associated down-glacier shallowing of the fjord. The velocity structure of that part of the glacier, therefore, most likely reflects relatively high basal drag at this subglacial 5 pinning point, rather than ungrounding.

Many tidewater glaciers exhibit increased transverse crevassing towards the terminus, due to extending flow rates (e.g., Vieli et al., 2000; O'Neel et al., 2001; Benn et al., 2007a). On Kronebreen, the pattern of crevasses in the terminal zone is complex, reflecting varying flow conditions in the lowermost $12 \mathrm{~km}$ of the glacier. Evidence from 10 photogrammetric measurements for extending flow within a few hundreds of metres of the calving front suggests that transverse crevasses may be reactivated in this area, with depths of ca. $28 \mathrm{~m}$ indicated by the Nye model. Crevasses are advected from the zone of extending flow to the terminus, and are thus important for the calving process, as they provide lines of weakness along the terminus where the glacier will break when 15 subjected to additional forces (Dowdeswell, 1989; Warren et al., 1995b; O'Neel et al., 2007).

The relationship between velocity structure, crevasse formation, and calving events at Kronebreen is therefore more complex than that envisaged in the crevasse-depth calving model of Benn $(2007 a, b)$. In the model, crevasse depth is calculated from the local, instantaneous strain rate, and no account is taken of antecedent conditions. In reality, however, crevasses will take a finite length of time to close when transported beyond an area of extending flow, providing inherited lines of weakness in areas of neutral or compressive strain. This emphasizes the fact that the model can only provide a first-order approximation of the calving front position, based on an idealized representation of the calving process (Benn et al., 2007a).

\subsection{Seasonal variations in velocity and calving}

In 2008, the terminal part of Kronebreen experienced two major speed-ups with velocities more than twice the annual average. The first occurred at the end of June and

\section{Velocities and calving Kronebreen}

M. Sund et al.

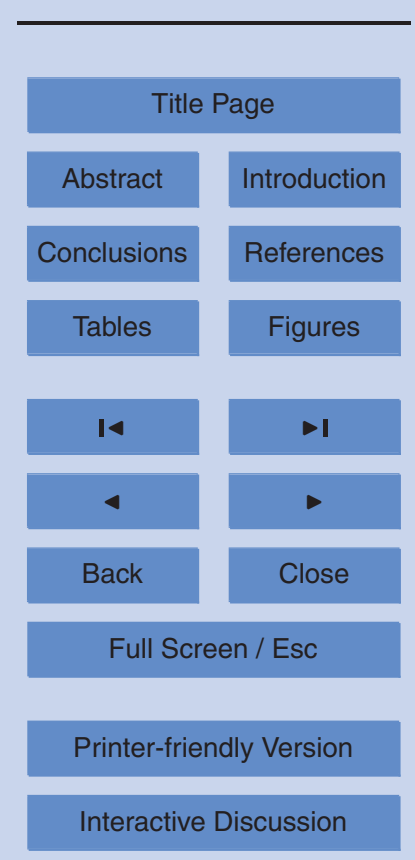


the second in late July, both at times of high air temperatures and high discharge in Bayelva (Fig. 4, Table 1). The high correlation between air temperature and Bayelva discharge indicates that they are good proxies for supraglacial melt rates, which corresponds to results from Ohmura (2001). The $\sim 3 \mathrm{~m}$ w eq. melt on the heavily crevassed

5 Kronebreen during summer 2008 amounts to approximately $1 \mathrm{~m} \mathrm{w}$ eq. more than what was measured on Kongsvegen (J. Kohler, 2008, personal communication), which currently has a even surface. Similar differences were found by Pfeffer and Bretherton (1987). This indicated that heavily crevassed glaciers may also have a larger meltwater input than glaciers with an even surface. The heavily crevassed lower part of 10 Kronebreen lacks an integrated supraglacial drainage system, and it is reasonable to assume that at least part of the surface meltwater is rapidly routed to the glacier bed. When influxes of surface-derived meltwater exceed the capacity of subglacial drainage systems, increased water storage at the bed causes decoupling and reduced frictional resistance (cf., Müller and Iken, 1973; Kamb et al., 1994; Vieli et al., 2004; Howat et al., 15 2010). It is notable in this respect that both velocity peaks are very short-lived, suggesting rapid reorganization of the subglacial drainage system to accommodate increased discharge.

The 2008 spring speed-up timing and seasonal velocity pattern is similar to those previously measured on Kronebreen (Voigt, 1967, 1979; Pillewiser and Voigt, 1968).

20 As a comparison the measurements of Pillewizer and Voigt (1968) pointed to a velocity decrease towards the annual average after the last velocity peak. Subtracting our mean photogrammetrical 3 June-3 August velocity of $2.41 \mathrm{~m} \mathrm{~d}^{-1}$ from mean GNSS velocities 30 May-29 August (Table 1) indicates mean velocities for August of $\sim 1 \mathrm{~m} \mathrm{~d}^{-1}$ when taking into consideration reduced velocity field between targets and stake position Kääb (2005). No special circumstances in weather occurred in August and thus the velocities correspond well with the meteorological parameters during this period. Pillewizer and Voigt (1968) found a rather constant velocity for the period October to mid June. Thus the pattern resembles the seasonal pattern found in many glaciers around the world and are interpreted as results of water input to the subglacial system

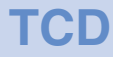

$5,41-73,2011$

\section{Velocities and calving Kronebreen}

M. Sund et al.

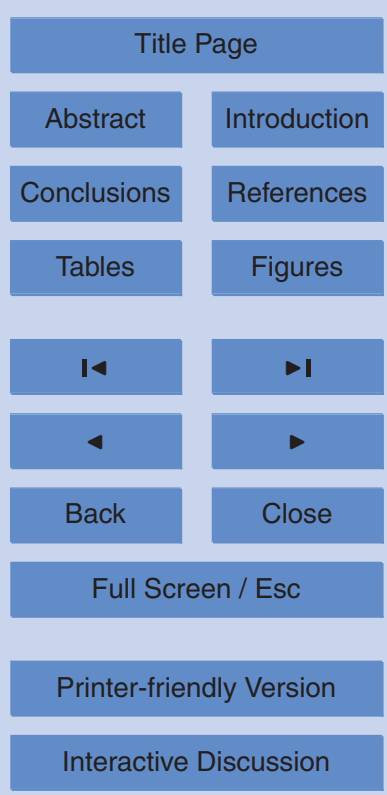


(e.g., Iken, 1978; Naruse et al., 1992; Mair et al., 2002, 2003; Howat, et al., 2010).

The rain event in September had a notable impact on the measured stake velocity. The mean GNSS velocity for September exceeds the mean of May-August velocity (Table 1). In contrast, in 1964 the velocities decreased to about half the annual value 5 during the first half of September (Voigt, 1979). Both Voigt (1967) and Melvold (1992) measured the lowest velocities in September. Assuming mean August velocities for days with little or no rain in September, the resulting velocities for the 12 days of rain is $3.7 \mathrm{~m} \mathrm{~d}^{-1}$ and is thus comparable to maximum velocities measured during summer. The 2008-2009 winter velocity of $1.48 \mathrm{~m} \mathrm{~d}^{-1}$ influenced by the September event was 10 still close to previous measurements.

Throughout the summer of 2008, the calving front oscillated around a similar position near the crest of the shallow, transverse ridge on the fjord floor. Because the ice front underwent little net change during this time interval, average ice velocities and calving rates will have been approximately equal. In the shorter term, however, there is little or no correlation between calving losses and ice velocity, at least within this dataset. The parallel fluctuations in ice velocity calving losses during June 2008 may reflect coupled responses to an increased availability of meltwater, following the transition from winter to summer conditions. However, throughout most of the record, fluctuations in velocity and calving show no consistent relationship. Yet, the advance of the front during winter indicates less calving during periods with lower velocities. Individual calving events appear to reflect a complex web of controls, including both contemporary and antecedent glaciological and meteorological conditions. This complexity may mean that, at an event level, calving is an essentially unpredictable, stochastic process.

\subsection{Long-term ice front position variations}

25 Retreat rates of tidewater glaciers are typically one order of magnitude or more higher than the rate of advance with the exceptions of surges, and the calving rate more than climate controls the position of the glacier's front (Molnia, 2007). Both before and after the 1948 surge the front positions aggregated in the area between the 1924 and

\section{Velocities and calving Kronebreen}

M. Sund et al.

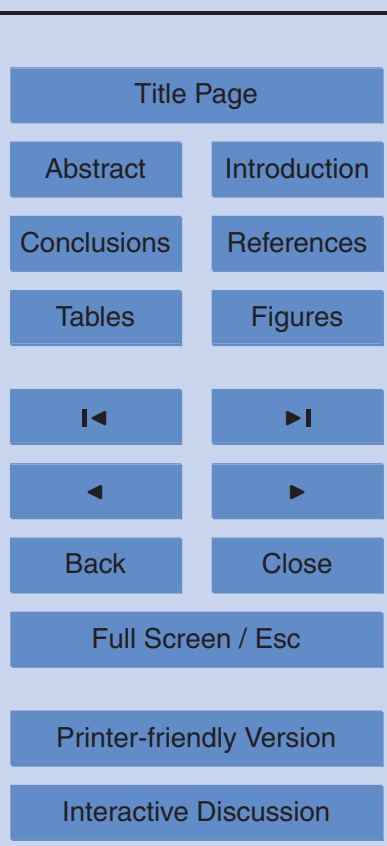


1970 positions (Liestøl, 1988). Inter annual variation were small and coincides with a shallower area (Fig. 5a) while the large retreat between 1923 and 1924 occurred outside this location in a deeper area.

The current width of Kronebreen could be compared with the situation during

5 Pillewizer's (1938) measurements in 1936 (Sect. 3.5), when a velocity of $3.9 \mathrm{~m} \mathrm{~d}^{-1}$ was measured around the centreline. While the somewhat lower velocities in the middle of the 1960's (Voigt, 1969) could stem from damming from Kongsvegen surge, which would affect the lower part more than the upglacier region. Kääb et al. (2005) found that the flow mode of the glacier up from the confluence with Kongsvegen has not changed 10 significantly since the 1960s. The highest velocities at the front averaged over a year were 2-2.15 $\mathrm{m}$ in 1986 (Lefauconnier, 1992) while they were $2 \mathrm{~m} \mathrm{~d}^{-1}$ in 1964 (Pillewizer and Voigt, 1968), which indicates rather stable situation. Our somewhat lower annual velocities (Table 1) are probably resulting from measurement both north of the maximum velocities (Voigt, 1967; Kääb et al., 2005) and location 1 km further upglacier. 15 Thus the variations in retreat rates since the Kongsvegen surge (Sect. 3.5) cannot be attributed to a change in velocities.

During the surge Kongvegen contributed to increased ice thicknesses in the terminal part of Kronebreen as Kongsvegen occupied about half of the ice cliff width (Voigt, 1966). Eventually Kongsvegen was progressively pushed aside by Kronebreen (Voigt, 20 1966; Kääb et al, 2005). By 1964, Kongsvegen was in quiescent flow mode and had considerably lower velocities than Kronebreen (Voigt, 1969). Therefore, part of the retreat may also have been encouraged by low ice flux "recharging" the southern part of the joint terminus area. As the Kronebreen front widened, an increasing proportion of the ice front consisted fast-flowing ice, increasing the ice flux to the calving front.

25 Variations in the ice flux from Infantfonna (Liestøl, 1988) likely connected to surges will also have a slight impact on the calving rate as the basin constitute $>10 \%$ of the total area draining Kronebreen.

There is little difference (0-400 m retreat) in front positions between 1964 and 1970 (Liestøl, 1988). The period of most rapid retreat, up to 10 times that of the previous

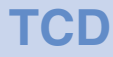

5, 41-73, 2011

\section{Velocities and calving Kronebreen}

M. Sund et al.

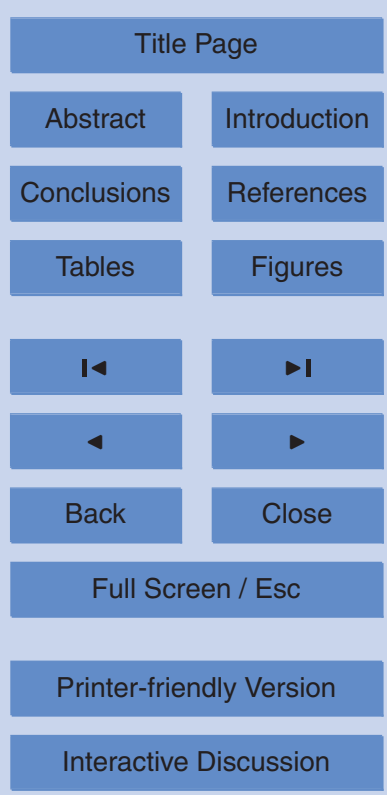


six years, is between 1970 and 1976, and was not marked by any significant air temperature or precipitation anomalies (met.no). Thus thinning does not appear as the main factor behind this retreat, which is rather attributed to bed topographic changes appearing at the location of front positions (Fig. 5). The highest retreat rate was in the 5 southern part of the joint Kronebreen-Kongsvegen terminus, an area of deep water, whereas retreat was slower adjacent to the promontory west of Colletthøgda (Fig. 5), this pattern is opposite to the previous six years where the retreat was largest in the north. Deep water at glacier termini encourages fast flow and increased longitudinal strain in the ice-cliff region, thus also encouraging crevasse propagation and calving 10 losses (Benn et al., 2007a). Also between 1983 and 1986 a rather strong retreat occurred (Lefauconnier et al., 1994) and could be linked to an overdeepening. A strong correlation between calving rates and water depth was shown for several other tidewater glaciers (Brown et al., 1982; Warren et al., 1995a) and Meier and Post (1987) showed that the calving rate is proportional to the water depth at the terminus. Hambergbreen experienced post surge retreat rates comparable to Kronebreen (Lefauconnier and Hagen, 1991) and the effect of post surge retreat due to calving into deep water is also emphasized by Pälli et al. (2003).

Since 1987, the calving front of Kronebreen has undergone relatively minor fluctuations, and has remained grounded on or close to a major transverse ridge extending southward across the fjord from the promontory west of Colletthøgda. During this period, the widening of the Kronebreen front towards Kongsvegen has been minimal (Kääb et al., 2005). This stabilization of the front thus appears to reflect mainly topographic factors. Indeed, the current front position of Kronebreen is a classic "pinning point", where shallow water and a fjord narrowing encourage relatively high resistance to flow (cf. Warren, 1992; Benn, 2007a). In the last few years (2007-2010), there has been some retreat in southern part of the front, while the other areas have minor changes. If this continues, and the glacier front pulls back from the transverse ridge, a period of more rapid retreat may be initiated as the glacier retreats through overdeepenings, provided no surges occurs. To some extent, this retreat may be mitigated by

\section{TCD}

$5,41-73,2011$

\section{Velocities and calving Kronebreen}

M. Sund et al.

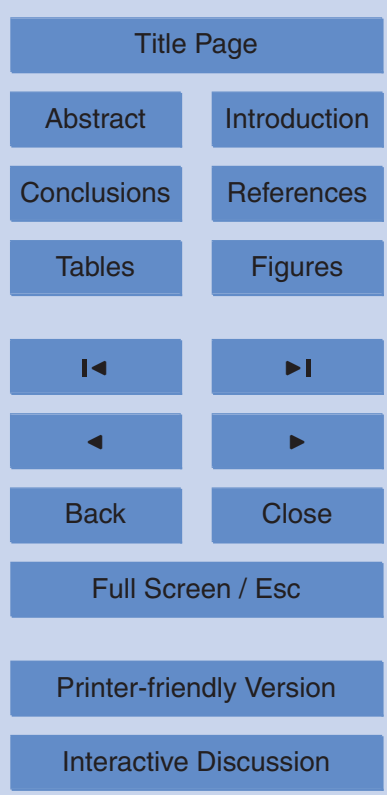


the longitudinal ridge on the bed, which may provide some degree of support for the ice.

The stable long-term pattern of ridges and depressions in the 1964 and 2007 DTMs (Sect. 4.1), a period when the glaciers were readjusting after the surge, indicates that 5 the surface topography reflects the bed topography. The elevation changes found between 1964 and 2007 may be a result of several processes. The ice flux was reduced as Kongsvegen went into quiescent phase dynamics, and a larger part of the ice front width was occupied by Kronebreen. The latter may also, being a surge-type glacier, be subject to reduced ice flux even if the fast-flowing mode to a larger degree than on other Svalbard glaciers compensates the ice loss and melt.

\section{Conclusions}

Glacier calving and retreat account for a large part of the ablation of tidewater glaciers, still the dynamics of calving is poorly known. We have investigated small and larger scale controls on calving of Kronebreen and tested the crevasse-depth calving model 15 of Benn et al. (2007a, b). The interaction between crevasse formation, current velocity structure and calving events at Kronebreen is found to be more complex than introduced in the crevasse-depth calving model.

Our study provides the to date most detailed data of Kronebreen for the period from spring speed-up to past summer maximum velocities. This enables a comparison between velocities and meteorological parameters showing that an increase in temperature and precipitation closely influences the front velocities of Kronebreen. However, no correspondence between velocity variation and calving could be extracted along the investigated transect. Heavy rain events in September, normally a period with very low velocities at this glacier, caused a higher average velocity during this month, that average for the three summer months autumn. The current velocities are rather similar to those measured during the last decades; however possible future increase in meltwater production could have an impact on the glacier velocities.

\section{Velocities and calving Kronebreen}

M. Sund et al.

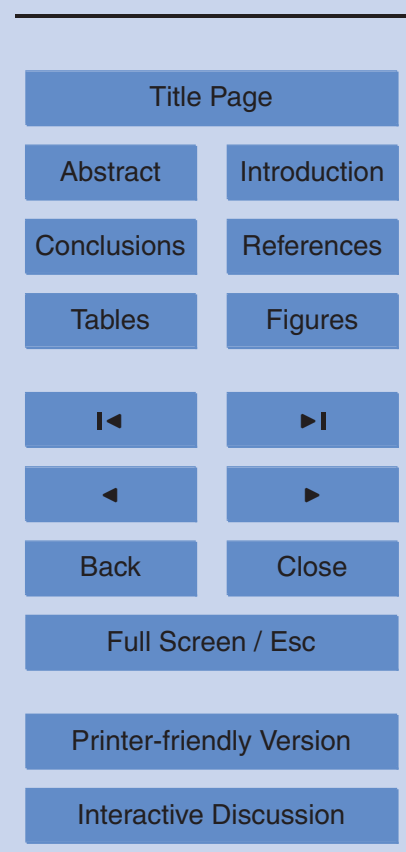


The Kronebreen ice cliff is partly shared with two other glaciers; Infantfonna and Kongvegen. Interactions due to surge-type dynamics and especially quiescent phase affect the ice flux to the terminus and thus the calving rate. Yet, the factor found to have largest impact on the specific retreat, is the water depth. Rapid inter- and multi annual 5 retreat of the glacier front corresponds with increased water depths in the terminus area. Thus the bed topography is found to be an important control on the retreat, not unlike several other tidewater glaciers.

Acknowledgement. We are grateful to the French Space Agency IPY-SPIRIT programme, $\varnothing$. Tappel, Norwegian Mapping Authority, Norwegian Hydrographic Service, the Norwegian Me10 teorological Institute, the Norwegian Water Resources and Energy Directorate and J. Kohler, Norwegian Polar Institute for kindly providing access to data. D. I. Benn is acknowledged for valuable input to the manuscript and language correction. Thanks also to K. Johansen for technical support. M. Sund was partly supported by Svalbard Science Forum's Arctic Fieldwork. Grant. This work is a contribution to the IPY-Glaciodyn project, funded by the Research Council

\section{References}

Alley, R. B., Horgan, H. J., Joughin, I. Cuffey, K. M., Dupont, T. K., Parizek, B. R., Anandakrishnan, S., and Bassis, J. A.: Simple law for ice-shelf calving, Science, 322(5906), 1344, doi:10.1126/science.1162543, 2008.

Andersen, M. L., Larsen, T. B., Nettles, M., Elosegui, P., van As, D., Hamilton, G. S., Stearns, L. A., Davis, J. L., Ahlstrøm, A. P., de Juan, J., Ekström, G., Stenseng, L., Khan, S. A., Forsberg, R., and Dahl-Jensen, D.: Spatial and temporal melt variability at Helheim Glacier, East Greenland, and its effect on ice dynamics, J. Geophys Res., 114, F04041, doi:10.1029/2010JF001760, 2010.

25 Benn, D. I., Hulton, N., and Mottram, R.: "Calving laws", "sliding laws" and the stability of tidewater glaciers, Ann. Glaciol., 46, 123-130, 2007a.

Benn, D. I., Warren, C. R., and Mottram, R. H.: Calving processes and the dynamics of calving glaciers, Earth-Sci. Rev., 82, 143-179, 2007b. 
Björnsson, H., Pálsson, F., and Guðmundsson, S.: Jokulsárlon at Breiðamerkursandur, Vatnajökull, Iceland: 20th century changes and future outlook, Jökull, 50, 1-18, 2001.

Błaszczyk, M., Jania, J. A., and Hagen, J. O.: Tidewater glaciers of Svalbard: recent changes and estimates of calving fluxes, Pol. Polar Res., 30(2), 85-142, 2009.

5 Bouillon, A., Bernard, M., Gigord, P., Orsoni, A., Rudowski, V., and Baudoin, A.: SPOT 5 HRS geometric performances: using block adjustment as a key issue to improve quality of DEM generation, ISPRS J. Photogramm., 60(3), 134-146, 2006.

Brown, C. S., Meier, M. F., and Post, A.: Calving speed of Alaska tidewater glaciers with applications to the Columbia Glacier, Alaska, US Geological Survey Professional Paper 1258-C, 101982.

Dowdeswell, J. A.: On the nature of Svalbard icebergs, J. Glaciol., 35, 224-234, 1989.

Dowdeswell, J. A., Hagen, J. O., Bjornsson, H., Glazovsky, A. F., Harrison, W. D., Holmlund, P., Jania, J., Koerner, R. M., Lefauconnier, B., Ommanney, C. S. L., and Thomas, R. H.: The mass balance of circum-Arctic glaciers and recent climate change, Quaternary Res., 48, 1-14, 1997.

Eiken, T. and Sund, M.: Various photogrammetric methods applied on Svalbard glaciers: accuracy and challenges, submitted to The Cryosphere, 2011.

Hooke, R.: LeB. Principles of glacier mechanics, Second edition, Cambridge University Press, Cambridge, 2005.

20 Howat, I. M., Joughin, I., and Scambos, T. A.: Rapid changes in ice discharge from Greenland outlet glaciers, Science, 315, 1559-1561, 2007.

Howat, I. M., Box, J. E., Ahn, Y., Herrington, A., and McFaddenen, E. M.: Seasonal variability in the dynamics of marine-terminating outlet glaciers in Greenland, J. Glaciol., 56(198), 601613, 2010.

Iken, A.: Variations of surface velocities of some Alpine glaciers measured at intervals of a few hours. Comparison with Arctic glaciers, Z. Gletscherkd. Glazialgeol., 13(1/2), 1977, 23-35, 1978.

Iken, A. and Bindschadler, R. A.: Combined measurements of subglacial water pressure and surface velocity of Inlendengletscher, Switzerland: conclusions about drainage system and $30 \quad$ sliding mechanism, J. Glaciol. 32(110), 101-117, 1986.

Kamb, B., Engelhardt, H., Fahnestock, M. A., Humphrey, N., Meier, M., and Stone, D.: Mechanical and hydrologic basis for the rapid motion of a large tidewater glacier 2. Interpretation, J. Geophys. Res., 99, 15231-15244, 1994.

\section{Velocities and calving Kronebreen}

M. Sund et al.

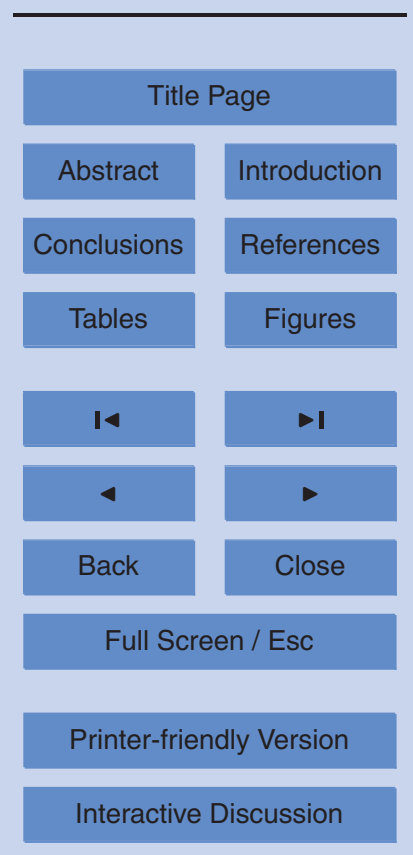


Korona, J., Berthier, E., Bernard, M., Rémy, F., and Thouvenot, E.: SPIRIT. SPOT 5 stereoscopic survey of Polar ice: Reference images and topographies during the Fourth International Polar Year (2007-2009), ISPRS. J. Photogramm. Remote Sens., 64(2), 2823-2830, 2009.

5 Krimmel, R. M.: Photogrammetric dataset, 1957-2000, and bathymetric measurements for Columbia Glacier, Alaska, US Geol. Surv. Water-Resour. Invest. Rep. 01-4089, 2001.

Kääb, A., Lefauconnier, B., and Melvold, K.: Flow field of Kronebreen, Svalbard, using LANDSAT 7 and ASTER data, Ann. Glaciol., 42, 7-13, 2005.

Lefauconnier, B.: Fluctuations glaciaires dans le Kongsfjord, baie du Roi, $79^{\circ} \mathrm{N}$, Spitsberg: analyses et consequences. (Glacier fluctuations in Kongsfjorden $79^{\circ} \mathrm{N}$, Spitsbergen: analyses and consequences). Unpublished thesis, Universite de Grenoble, 1987.

Lefauconnier, B.: Recent fluctuations of glaciers in Kongsfjorden, Spitsbergen, Svalbard $\left(79^{\circ} \mathrm{N}\right)$, Polar Geogr. Geol., 16(3), 226-233, 1992.

Lefauconnier, B. and Hagen, J. O.: Surging and calving glaciers in Eastern Svalbard, Nor.

15 Polarinst. Medd., 116, 1991.

Lefauconnier, B., Hagen, J. O., and Rudant, J. P.: Flow speed and calving rate of Kronebreen glacier, Svalbard, using SPOT images, Pol. Res., 13(1), 59-65, 1994.

Lefauconnier, B., Massonnet, D., and Anker, G.: Determination of ice flow velocity in Svalbard from ERS-1 interferometric observations, Mem. Nat. Inst. Polar Res., Special Issue, 54, 279 290, 2001.

Liestøl, O.: The glaciers in the Kongsfjorden area, Spitsbergen, Norsk Geogr. Tidsskr., 42, 231-238, 1988.

Mair, D., Nienow, P., Sharp, M. J., Wohlleben, T., and Willis, I.: Influence of subglacial drainage system evolution on glacier surface motion: Haut Glacier d'Arolla, Switzerland, J. Geophys. Res., 107(B8), 2175, doi:10.1029/2001JB000514, 2002.

Mair, D., Willis, I., Fischer, U. H., Hubbard, B., Nienow, P., and Hubbard, A.: Hydrological controls on patterns of surface, internal and basal motion during three "spring events": Haut Glacier d'Arolla, Switzerland, J. Glaciol., 49(167), 555-567, 2003.

Meehl, G. A., Stocker, T. F., Collins, W. D., Friedlingstein, P., Gaye, A. T., Gregory, J. M., Kitoh, A., Knutti, R., Murphy, J. M., Noda, A., Raper, S. C. B., Watterson, I. G., Weaver, A. J., and Zhao, Z.-C.: Global Climate Projections, in: Climate Change 2007: The Physical Science Basis. Contribution of Working Group I to the Fourth Assessment Report of the Intergovernmental Panel on Climate Change, edited by: Solomon, S., Qin, D., Manning, M., Chen, Z.,

\section{Velocities and calving Kronebreen}

M. Sund et al.

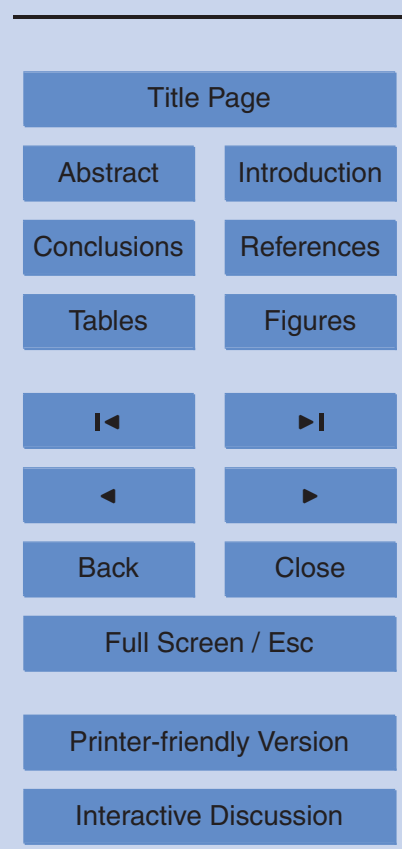


Marquis, M., Averyt, K. B., Tignor, M., and Miller, H. L., Cambridge University Press, Cambridge, UK and New York, NY, USA, 2007.

Meier, M. F. and Post, A. S.: Fast tidewater glaciers, J. Geophys. Res., 92, 9051-9058, 1987.

Mevold, K.: Studie av brebevegelse på Kongsvegen og Kronebreen, Svalbard. (A study of 5 glacier movement on Kongsvegen and Kronebreen, Svalbard) Oslo, Universitetet i Oslo, (Rapportserie i Naturgeografi I.) 1992.

Molnia, B. F.: Late nineteenth to early twenty-first century behaviour of Alaskan glaciers as indicators of changing regional climate, Global Planet. Change, 56, 23-54, 2007.

Mottram, R. H. and Benn, D. I.: Testing crevasse depth models: a field study at Breiðamerkurjökull, Iceland, J. Glaciol., 55(192), 746-752, 2009.

Müller, F., and Iken, A.: Velocity Auctuations and water regime of Arctic valley glaciers. Union Geodesique et Geophysique Intemationale. Association Intemationale d' Hydrologie Scientifique. Commission de Neiges et Glaces. Symposium on the Hydrology of Glaciers, Cambridge, 7-3 September 1969, 165-182, 1973.

Naruse, R., Fukami, H., and Aniya, M.: Short-term variations in flow velocity of Glaciar Soler, Patagonia, Chile, J. Glaciol., 38(128), 152-156, 1992.

Nick, F. M., van der Veen, C. J., Vieli, A., and Benn, D. I.: A physically based calving model applied to marine outlet glaciers and implications for the glacier dynamics, J. Glaciol., 56(199), 781-794, 2010.

20 Nye, J. F.: The distribution of stress and velocity in glaciers and ice sheets, Proc. Royal Soc. A, 239, 113-33, 1957.

Ohmura, A.: Physical basis for the temperature-based melt-index method, J. Appl. Meteorol., 40(4), 753-761, 2001.

O'Neel, S., Echelmeyer, K. A., and Motyka, R. J.: Short-term flow dynamics of a retreating tidewater glacier: LeConte Glacier, Alaska, USA, J. Glaciol., 47(159), 567-578, 2001.

Pettersson, L.-E.: Hydrological Investigations in Svalbard, Proceedings from Nordic Hydrological Conference 1994, Torshavn, Faroe Islands, NHP-report no 34, 1994.

Pfeffer, W. T. and Bretherton, C. S.: The effect of crevasses on the solar heating of a glacier surface, in: The Physical Basis of Ice Sheet Modelling, edited by: Waddington, E. D. W. and

$30 \quad$ Walder, J. S., IAHS publ. no. 170, Vancouver, British Columbia, 191-205, 1987.

Pillewizer, W.: Die Kartographischen und Gletcherkundlichen Ergenbnisse der Deutchen Spitsbergen Expedition 1938 (The catographic and glacier related results of the German Spitsbergen Expedition, 1938), Petermann. Geogr. Mitt., Ergänzungsband, 238, 36-38, 1939.

\section{Velocities and calving Kronebreen}

M. Sund et al.

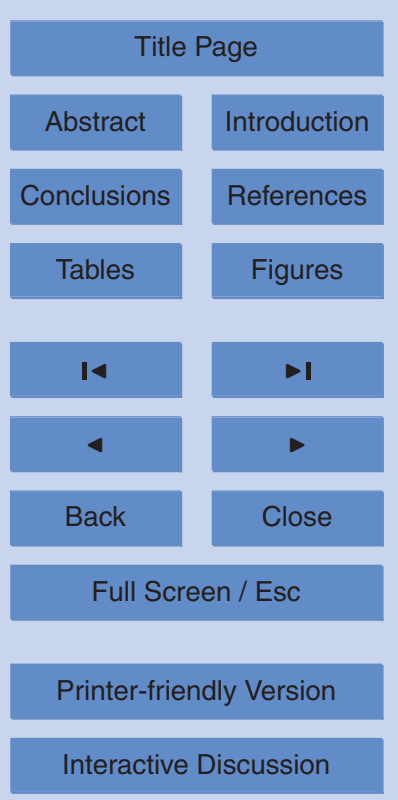


Pillewizer, W. and Voigt, U.: Block movement of glaciers. Die wissenschaftlichen Ergebnisse der deutschen Spitzbergenexpedition 1964-1965, Geodat. Geophys. Veröff., 111(9), 1-138, 1968.

Pälli, A., Moore, J. C., Jania, J., and Glowacki, P.: Glacier changes in southern Spitsbergen, Svalbard, 1901-2000, Ann. Glaciol., 37, 219-225, 2003.

Rolstad, C.: Satellitt- og flybilder til bestemmelse av bredynamikk (Satellite and aerial images used for determination of glacier dynamics), M.Sc. thesis, University of Oslo, 1995.

Sikonia, W. G.: Finite-element glacier dynamic model applied to Columbia Glacier, Alaska, US Geological Survey Professional Paper 1258-B, 74, 1982.

10 Sund, M., Eiken, T., Hagen, J. O., and Kääb, A.: Svalbard surge dynamics derived from geometric changes, Ann. Glaciol., 50(52), 50-60, 2009.

Van der Veen, C. J.: Tidewater calving, J. Glaciol., 42(141), 375-385, 1996.

Van der Veen, C. J.: Calving glaciers, Prog. Phys. Geog., 26(1), 96-122, 2002.

Vieli, A., Funk, M., and Blatter, H.: Tidewater glaciers: frontal flow acceleration and basal 15 sliding, Ann. Glaciol., 31, 217-221, 2000.

Vieli, A., Jania, J., Blatter, H., and Funk, M.: Short-term velocity variations on Hansbreen, a tidewater glacier in Spitsbergen, J. Glaciol., 50(170), 389-398, 2004.

Voigt, U.: The determination of the direction of movement on glacier surfaces by terrestrial photogrammetry, J. Glaciol., 6(45), 359-367, 1966.

20 Voigt, U.: Ergebnisse der Bewegungsmessungen an Kongsvegen und Kronebre: wissenschaftliche Ergebnisse der Deutschen Spitsbergenexpedition 1964-65, Geodät. Geophys. Veröff. (Berlin), 3(9), 70-98, 1967.

Voigt, U.: Ergebnisse der Bewegungsmessungen an Kongsvegen und Kronebre. Wissenschaftliche Ergebnisse der detutschen Spitzbergenexpedition 1964-1965. Geodät. Geophys. Veröff. Reihe III, Heft 9, Berlin, 1969.

Voigt, U.: Zur Blockbewegung der Gletscher, Geodät. Geophys. Veröff. Reihe III, Heft 44, 1979.

Wingham, D. J., Wallis, D. W., and Shepherd, A.: Spatial and temporal evolution of Pine Island Glacier thinning 1995-2006, Geophys. Res. Lett., 36, L17501, doi:10.1029/2009GL039126, 2009.

30 Warren, C. R.: Iceberg calving and the glacioclimatic record, Prog. Phys. Geog., 16(3), 253282, 1992.

Warren, C. R., Greene, D., and Glaccer, N. F.: Glacial Upsala, Patagonia: rapid calving retreat in fresh water, Ann. Glaciol., 21, 311-316, 1995a.

\section{Velocities and calving Kronebreen}

M. Sund et al.

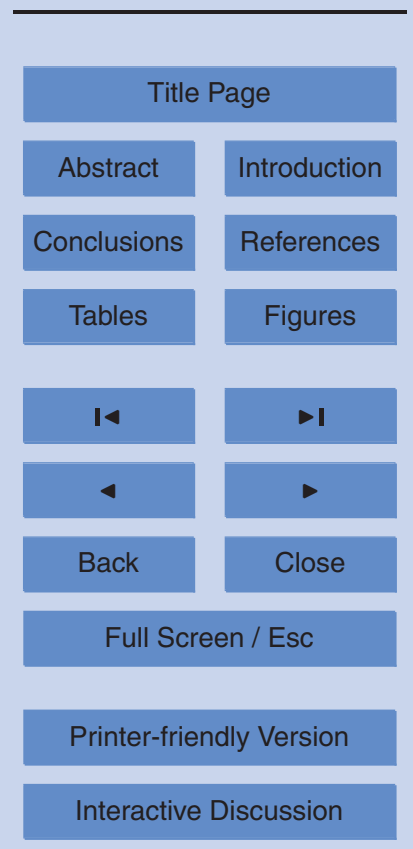


Warren, C. R., Glasser, N. F., Harrison, S., Winchester, V., Kerr, A. R., and Rivera, A.: Characteristics of tide-water calving at Glaciar San Rafael, Chile, J. Glaciol., 41, 273-89, 1995b.

Zwally, H. J., Abdalati, W., Herring, T., Larson, K., Saba, J., and Steffen, K.: Surface meltinduced acceleration of Greenland ice-sheet flow, Science, 297(5579), 218-222, 2002.

$5,41-73,2011$

\section{Velocities and calving Kronebreen}

M. Sund et al.

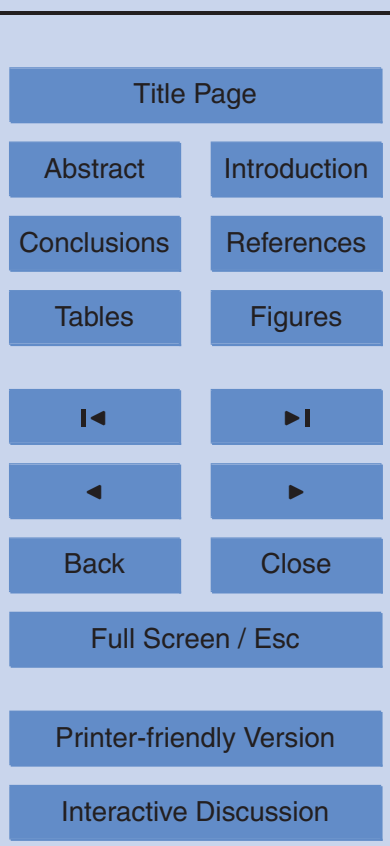


$5,41-73,2011$

\section{Velocities and calving Kronebreen}

M. Sund et al.

Table 1. Average Global Navigation Satellite Systems (GNSS) velocities for different periods.

\begin{tabular}{llll}
\hline Period & Velocity & Standard deviation & Method \\
\hline 30 May-29 August 2008 & 1.82 & $<1 \mathrm{~cm} \mathrm{~d}^{-1}($ accuracy $<1 \%)$ & GNSS \\
29 August-28 September 2008 & 1.82 & $<1 \mathrm{~cm} \mathrm{~d}^{-1}($ accuracy $<1 \%)$ & GNSS \\
30 May 2008-17 May 2009 & 1.82 & $<1 \mathrm{~cm} \mathrm{~d}^{-1}($ accuracy $<1 \%)$ & GNSS \\
28 September 2008-17 May 2009 & 1.82 & $<1 \mathrm{~cm} \mathrm{~d}^{-1}($ accuracy $<1 \%)$ & GNSS \\
\hline
\end{tabular}

Title Page

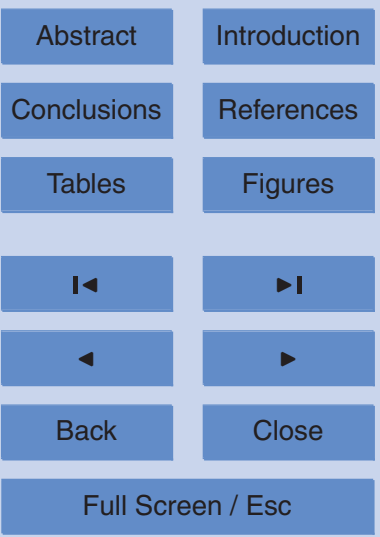

Printer-friendly Version

Interactive Discussion 


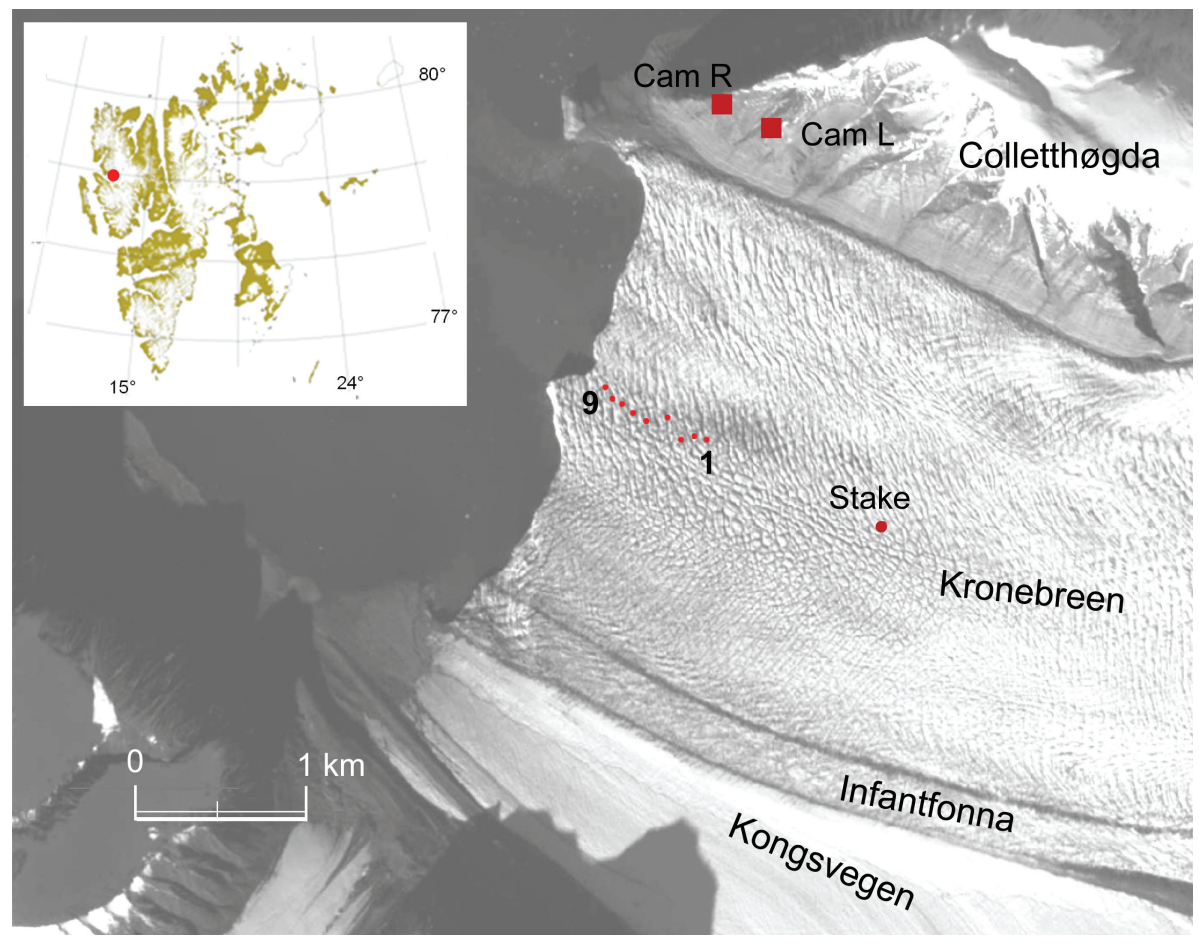

Fig. 1. Front of Kronebreen, Infantfonna and Kongsvegen. Locations of cameras (R-right, Lleft), stake and the longitudinal transect of the nine target points measured (1-9). Background image SPOT 5: Système Probatoire pour l'Observation de la Terre (SPOT) Spirit Program( Centre National d'Etudes, France (CNES) 2007 (2007) and SPOT Image 2007 all rights reserved. Inset: location of Kronebreen in Svalbard.

\section{TCD}

$5,41-73,2011$

\section{Velocities and calving Kronebreen}

M. Sund et al.

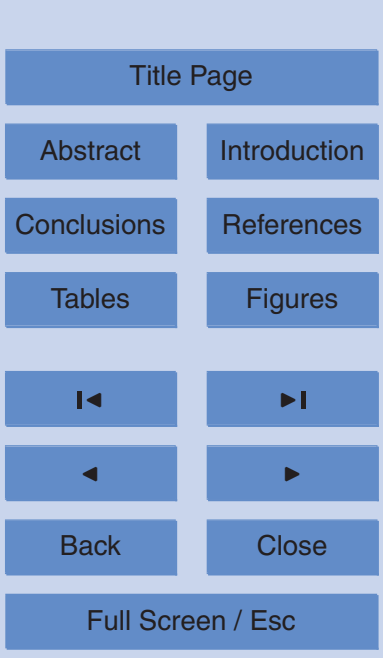

Printer-friendly Version

Interactive Discussion 
(a)

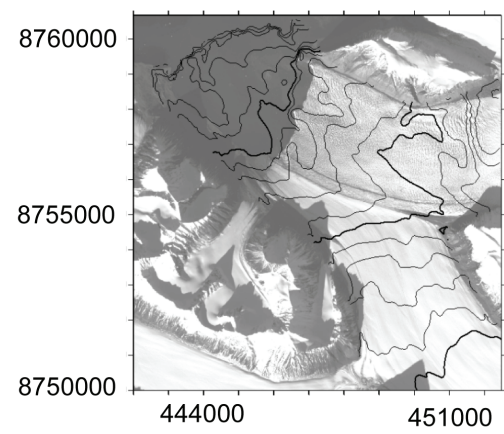

(b)

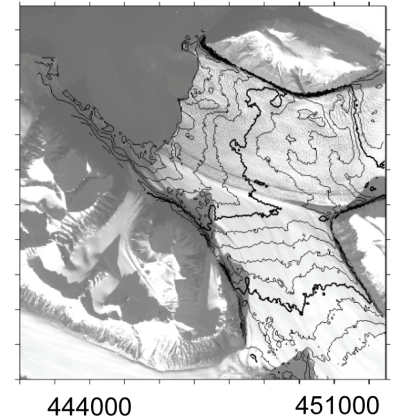

(c)

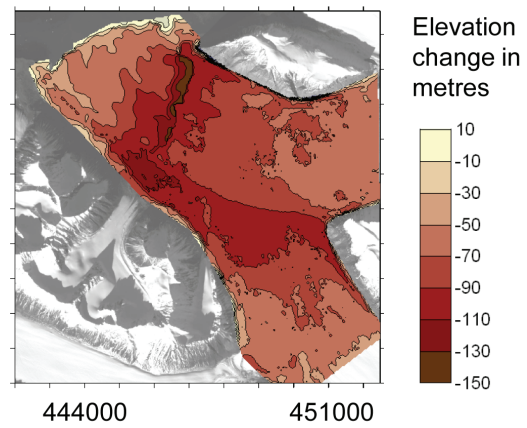

Fig. 2. (a) 1964 (Voigt, 1966) and (b) 2007 (SPOT 5) surface topography of Kronebreen. Red oval shows longitudinal surface ridges, while blue ovals shows a transversal surface ridge. For (a) and (b) elevation contour line start at $0 \mathrm{~m}$ a.s.l. and are displayed every $20 \mathrm{~m}$. (c) Elevation changes on Kronebreen between 1964 and 2007. Background image SPOT 5. Système Probatoire pour l'Observation de la Terre (SPOT) Spirit Program@ Centre National d'Etudes, France (CNES) 2007 (2007) and SPOT Image 2007 all rights reserved. 
a

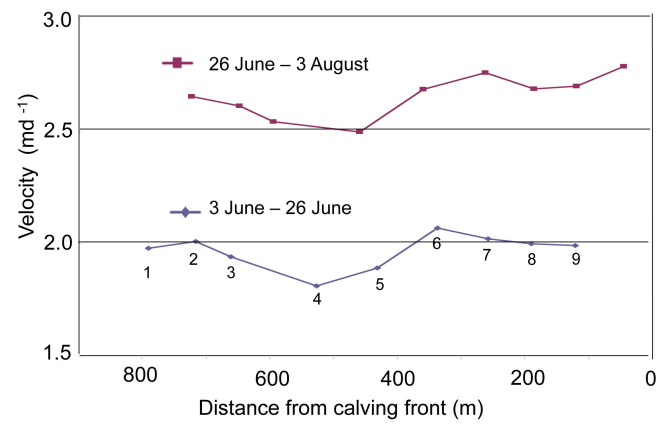

$\mathrm{b}$

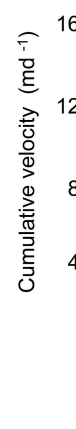

60

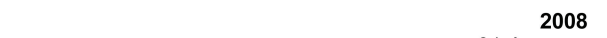

- 24 - 31 July

- 17 - 24 July

- 10 - 17 July

- 1 - 10 July

- 24 June

- 17 - 24 June

- 10 - 17 June

- 3 - 10 June

0

\section{Velocities and calving Kronebreen}

M. Sund et al.

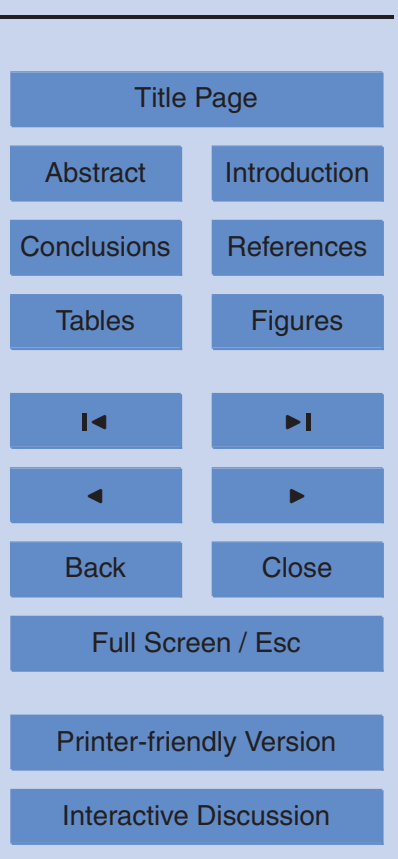

Fig. 3. (a) Multiday cumulative velocities for the different targets in Fig. 1 (1 uppermost, 9 closest to front). The highest velocity gradient occur between points 5 and 6 , where cumulative velocities rises from 146.5 to $153.7 \mathrm{~m} \mathrm{~d}^{-1}$, which also exposes the highest velocity. (b) Period averages in velocities for the longitudinal transect (targets 1-9) from stereo results. Target locations showed according to target 9 reaching terminus at end of period 2 . The velocity decreases and increases occur in the same area during both periods. 


\section{TCD}

$5,41-73,2011$

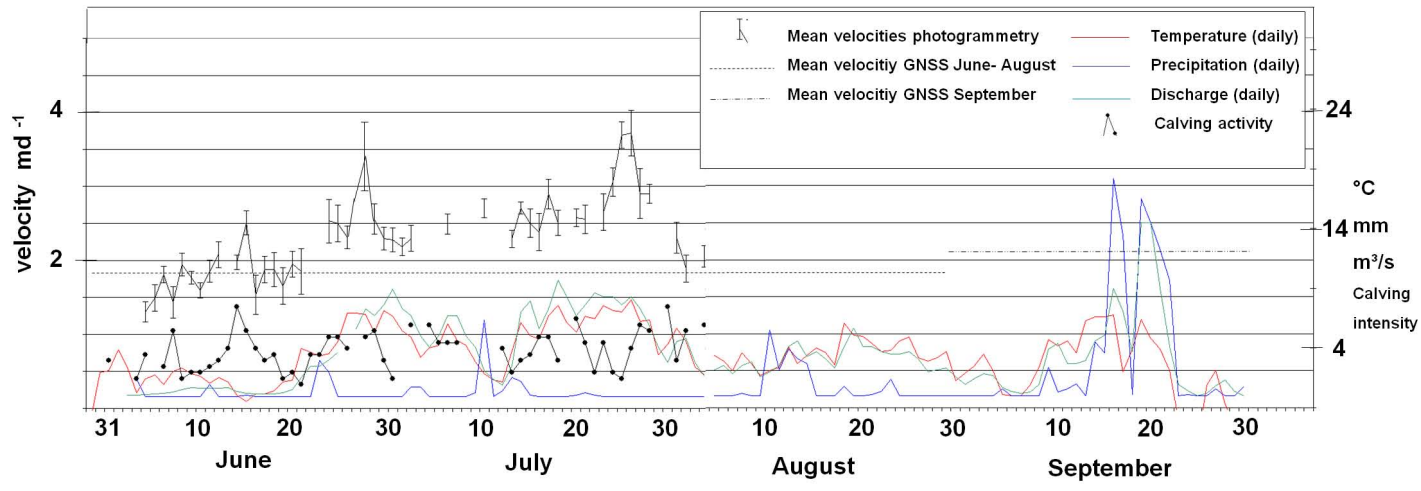

Fig. 4. $24 \mathrm{~h}$ velocities (except from $25-26$ June which is $36 \mathrm{~h}$ ) from photogrammetry plotted together with temperature, precipitation, Ny-Ålesund (met.no), river discharge at Bayelva (NVE), calving activity and mean velocity from GNSS in the periods May-August and September.

\section{Velocities and calving Kronebreen}

M. Sund et al.
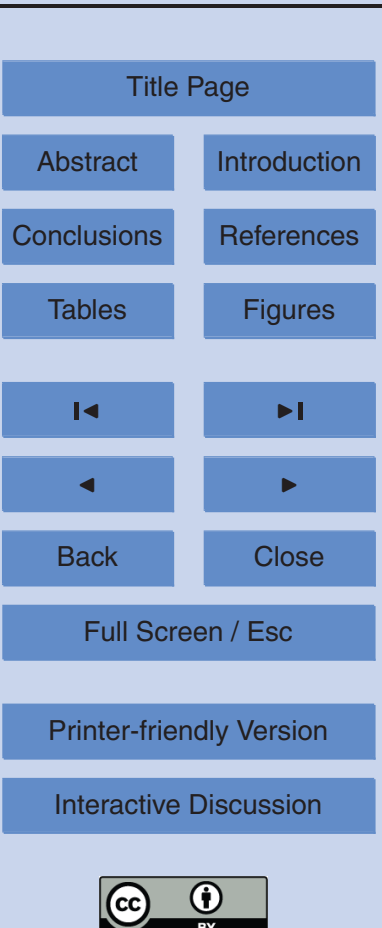

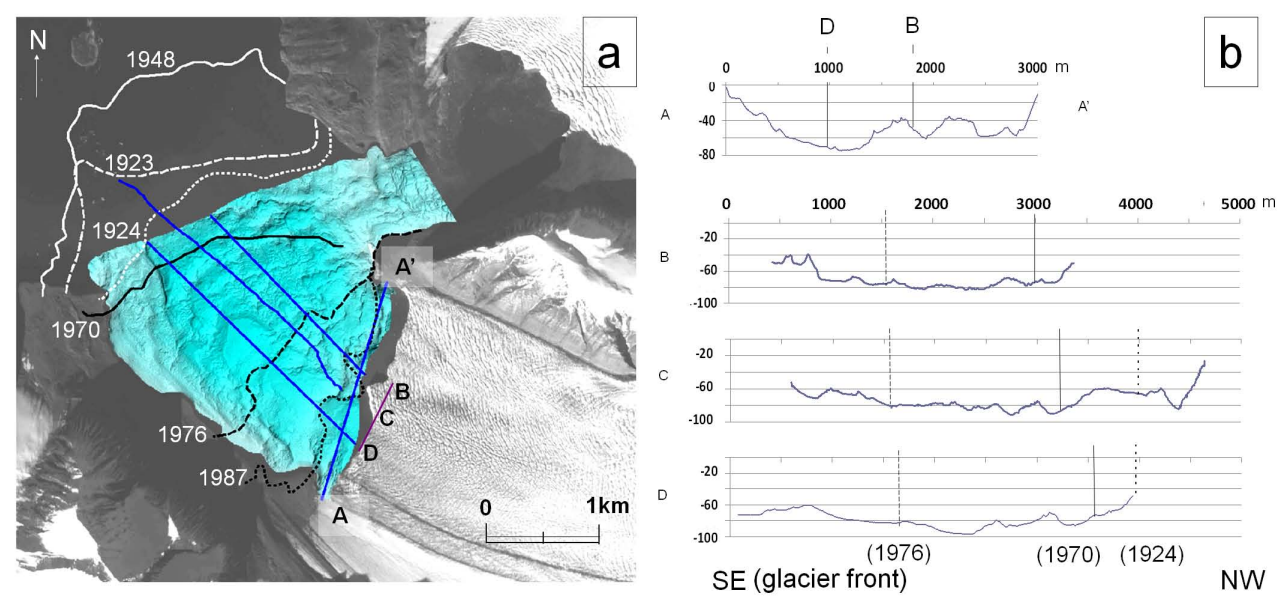

Fig. 5. (a) Shaded bathymetry relief (Norwegian Mapping Authority, Norwegian Hydrographic Service) and profile tracks (A-D), with front positions adapted from Liestøl (1988). Background image: SPOT 5. (b) Transversal profile $\left(A-A^{\prime}\right)$ positions of profiles $B$ and $D$ indicated. Along flow profiles are shown from southeast towards northwest (B-D). Profile $C$ is from $200 \mathrm{kHz}$ echo sounding, the others are derived by Norwegian Mapping Authority, Norwegian Hydrographic Service. Distances are measured from purple line along front in (a). Vertical lines indicate front positions in years corresponding to line legend in (a).

\section{Velocities and calving Kronebreen}

M. Sund et al.

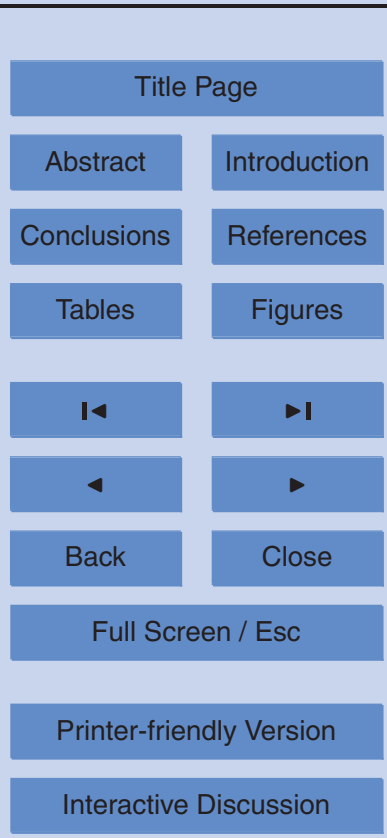




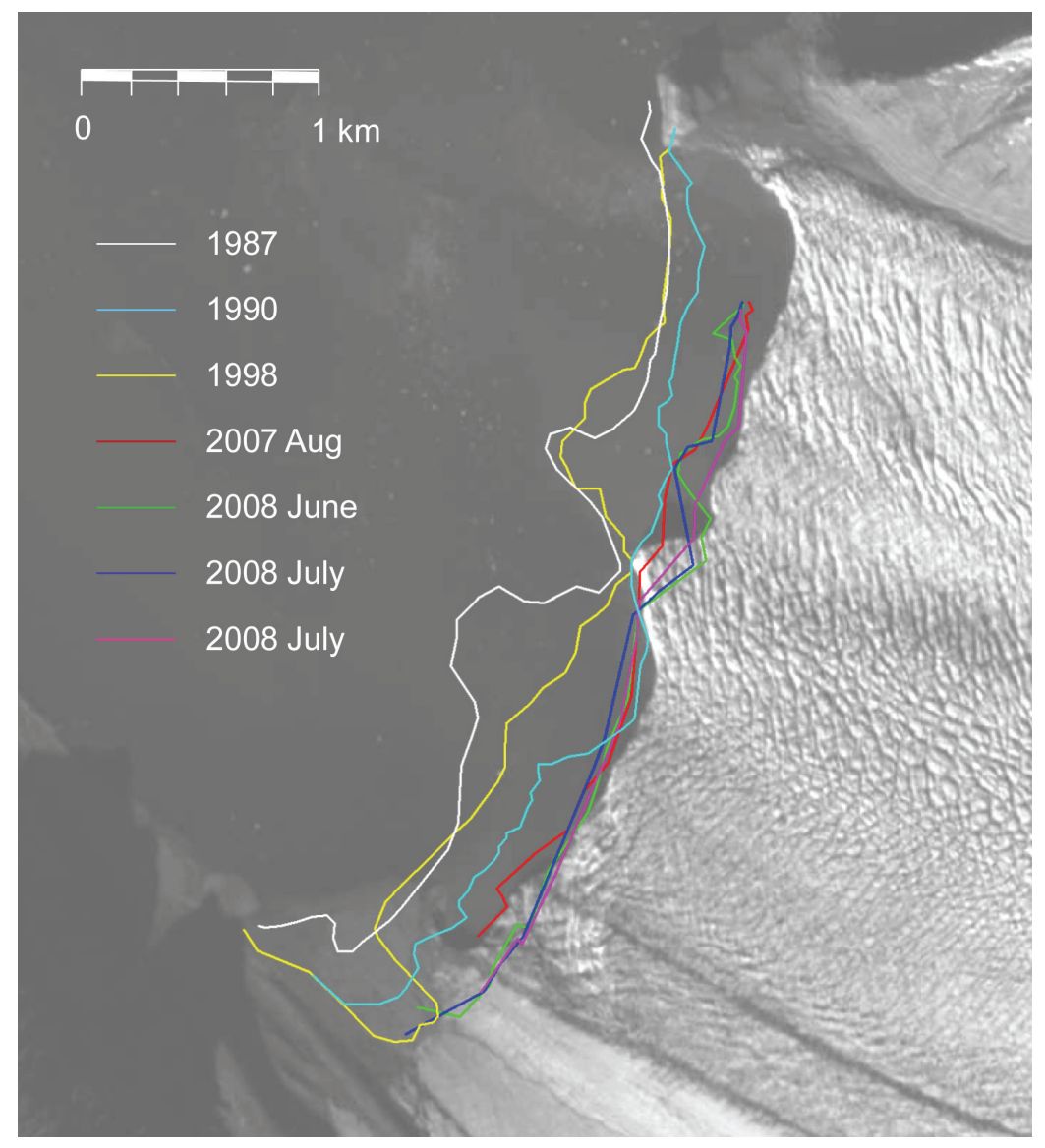

\section{TCD}

$5,41-73,2011$

\section{Velocities and calving Kronebreen}

M. Sund et al.

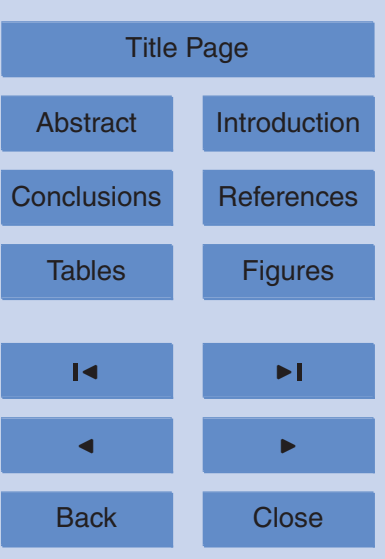

Full Screen / Esc

Printer-friendly Version

Interactive Discussion

Fig. 6. Glacier front fluctuations between 1987 and 2008. Background image: SPOT 5. Maximum retreat during this period is $\sim 700 \mathrm{~m}$ and minimum is $\sim 50 \mathrm{~m}$. The 1987, 1990 and 1998 positions are drawn from NPI maps Kongsfjorden (1990 and 2000 editions). 2007 and 2008 lines are from stereo photogrammetry. 